\title{
Data report: permeability of mud(stone) samples from IODP Sites C0006 and C0007, Nankai Trough Seismogenic Zone Experiment ${ }^{1}$
}

\author{
Mehmet Koray Ekinci, ${ }^{2}$ William J. Likos, ${ }^{3}$ Michael B. Underwood, ${ }^{2}$ and Junhua Guo ${ }^{2}$
}

\section{Chapter contents}

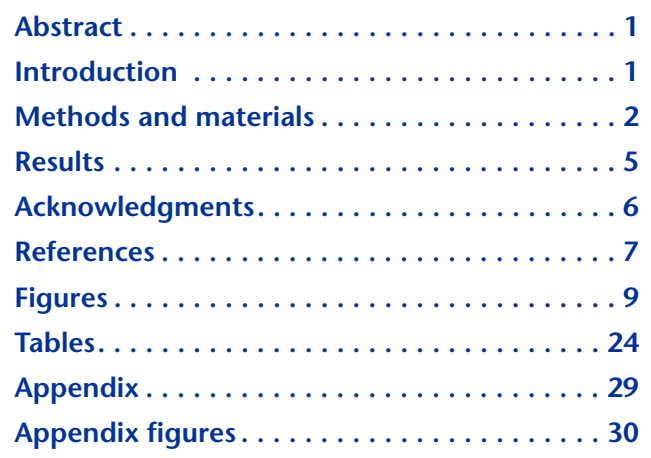

'Ekinci, M.K., Likos, W.J., Underwood, M.B., and Guo, J., 2011. Data report: permeability of mud(stone) samples from IODP Sites C0006 and C0007, Nankai Trough Seismogenic Zone Experiment. In Kinoshita, M., Tobin, H., Ashi, J., Kimura, G., Lallemant, S., Screaton, E.J., Curewitz, D., Masago, H., Moe, K.T., and the Expedition 314/315/316 Scientists, Proc. IODP, 314/315/316: Washington, DC (Integrated Ocean Drilling Program Management International, Inc.). doi:10.2204/iodp.proc.314315316.214.2011 2Department of Geological Sciences, 101 Geology Building, University of Missouri, Columbia MO 65211, USA. Correspondence author:

UnderwoodM@missouri.edu ${ }^{3}$ Department of Civil and Environmental Engineering, University of Missouri, Columbia MO 65211, USA.

\section{Abstract}

In this study, we executed constant-flow permeability tests in the horizontal (cross-core) and vertical (along-core) directions using 11 whole-round core specimens of mud(stone) from Integrated Ocean Drilling Program Nankai Trough Sites C0006 and C0007. The samples came from $\sim 34$ to 564 meters below seafloor and include lithostratigraphic Units II (accreted trench wedge) and III (upper Shikoku Basin facies). Effective isotropic confining stress during the tests was set at $0.55 \mathrm{MPa}(80 \mathrm{psi})$. At Site C0006, the highest value of vertical hydraulic conductivity $\left(K_{v}\right)$ is $1.60 \times 10^{-6}$ $\mathrm{cm} / \mathrm{s}$ and the lowest value of vertical hydraulic conductivity is $2.63 \times 10^{-10} \mathrm{~cm} / \mathrm{s}$. The highest value of horizontal hydraulic conductivity $\left(K_{\mathrm{h}}\right)$ is $2.07 \times 10^{-6} \mathrm{~cm} / \mathrm{s}$, and the lowest value of horizontal hydraulic conductivity is $3.25 \times 10^{-10} \mathrm{~cm} / \mathrm{s}$. The average ratio of horizontal to vertical intrinsic permeability $\left(k_{\mathrm{h}} / k_{\mathrm{v}}\right)$ is 4.27 . At Site $\mathrm{C0007}$, the highest value of vertical hydraulic conductivity is $1.24 \times 10^{-9} \mathrm{~cm} / \mathrm{s}$ and the lowest value of vertical hydraulic conductivity is $9.54 \times 10^{-10} \mathrm{~cm} / \mathrm{s}$. Horizontal hydraulic conductivity reaches a maximum of $1.15 \times 10^{-9} \mathrm{~cm} / \mathrm{s}$, and the lowest value of horizontal hydraulic conductivity is $8.09 \times 10^{-10} \mathrm{~cm} / \mathrm{s}$. The average ratio $k_{\mathrm{h}} / k_{\mathrm{v}}$ is 0.93 for specimens at Site C0007. Environmental scanning electron microscopy was used to evaluate the relation between sediment microstructure and anisotropy of permeability. The index of orientation does not vary significantly and shows a weak correlation with $k_{\mathrm{h}} / k_{\mathrm{v}}$ values.

\section{Introduction}

Accretionary prisms contain saturated sediments that are subject to intense deformation as a result of lithospheric plate convergence (e.g., Carson and Screaton, 1998). To better understand how the accretionary prism behaves in the Nankai Trough subduction zone, we measured the hydrological properties of wholeround specimens recovered at two Integrated Ocean Drilling Program (IODP) Expedition 316 sites (Fig. F1) (see the "Expedition 316 summary" chapter [Screaton et al., 2009a]). Permeability influences sediment consolidation and shear strength by governing pore fluid pressure and effective normal stress (Moore and Vrolijk, 1992; Saffer and Bekins, 2006). Elevated pore pressures (i.e., values greater than hydrostatic) play a critical role in the evolution of accretionary complexes, including the development of the dé- 
collement zone (Gamage and Screaton, 2006) and the taper angle of the accretionary wedge (Saffer and Bekins, 2002, 2006). By comparing hydrological properties within fault blocks and fault zones at various depths, the Nankai Trough Seismogenic Zone Experiment (NanTroSEIZE) will examine how geologic structures and permeability in the frontal Nankai accretionary prism might influence one another over a large range of effective stress values.

Previous laboratory tests of natural clay-rich sediment and shale reveal large ranges in values of intrinsic permeability $(k)$ and hydraulic conductivity $(K)$ because of differences in the material's mineral composition, texture, and porosity (Bennett et al., 1989; Neuzil, 1994; Dewhurst et al., 1999; Yang and Aplin, 2007; Gamage et al., 2011). The hydrological properties of sediments and sedimentary rocks depend on many factors inherited from the time of deposition, including grain size and shape, sorting, type of particle association and arrangement, magnitude and strength of the forces between particles, and different scales of fabric elements (Moon and Hurst, 1984; Bennett et al., 1989, 1991; Mitchell, 1993). Fabric, in small scales, is directly related to the aggregation of particles and very small pores. These aggregated particles and pores control the fluid flow (Olsen, 1960; Delage and Lefebvre, 1984), and the fabric can be highly anisotropic (Anandarajah and Kuganenthira, 1995). The anisotropy of permeability (e.g., Clennell et al., 1999; Bolton et al., 2000) is particularly important in studies of subduction zones because it influences a variety of behaviors that are related to tectonic loading and fault-induced deformation.

To establish the extent of anisotropy, comparisons are made between horizontal (cross-core) permeability $\left(k_{\mathrm{h}}\right)$ and vertical (along-core) permeability $\left(k_{\mathrm{v}}\right)$ at the same sampling depth. When $k_{\mathrm{h}}=k_{\mathrm{v}}$, the sediment is isotropic. In many cases, preferred alignment of platy mineral grains in sedimentary deposits results in $k_{\mathrm{h}}>k_{\mathrm{v}}$. The ratio of horizontal to vertical permeability $\left(k_{\mathrm{h}} / k_{\mathrm{v}}\right)$ for soils can range from $<1$ to $>10$ (Schwartz and Zhang, 2003). Permeability anisotropy usually varies with the thickness of sedimentary layers (varves, laminae, beds, etc.), depth of burial, and the magnitude of applied effective stress. As a general rule, long-term burial loading and chemical diagenesis impart changes in the volume and orientation of platy clay minerals in sedimentary basins. With deeper burial, the alignment of platy grains becomes almost perpendicular to the maximum principal effective stress (Sintubin, 1994; Kim et al., 1999; Aplin et al., 2006). Permeability should become more anisotropic in response to this evolving grain fabric because fluids physically seek the easiest flow path, which is usually along rather than across the direction of grain alignment.

In this report, we document the results of constantflow permeability tests completed at the University of Missouri (USA). Two holes were cored at Site C0006 and two holes were cored at Site C0007 during Expedition 316 (see the "Expedition 316 Site C0006" [Expedition 316 Scientists, 2009b] and "Expedition 316 Site C0007" [Expedition 316 Scientists, 2009c] chapters). Expedition 316 was designed to evaluate the deformation, inferred depth of detachment, structural partitioning, fault zone physical characteristics, and fluid flow at the frontal thrust and at the shallow portion of the megasplay system (Screaton et al., 2009b). At Site C0006, several subsidiary fault zones within the prism were penetrated before drilling was stopped because of poor conditions. The frontal thrust was successfully drilled at Site C0007, and fault material ranging from breccia to fault gouge was recovered (see the "Expedition 316 summary" chapter [Screaton et al., 2009a]). The 11 samples that we tested are from the hanging wall of the frontal thrust (see Moore et al., 2009), with subbottom depths ranging from 34 to $564 \mathrm{~m}$ coring depth below seafloor (CSF) (Fig. F2). The main purpose of this report is to document the anisotropy of permeability in the hanging wall of the frontal thrust.

\section{Methods and materials}

Yue et al. (submitted) provide a more detailed description of the procedures we used for testing permeability and imaging grain fabric. All of the specimens consist of hemipelagic mud with varying degrees of consolidation. We tested eight samples from the accreted trench wedge facies and three samples from the upper Shikoku Basin hemipelagic facies (Fig. F2). The dip of bedding surfaces relative to the horizontal plane is based on nearby measurements on split core (see the "Expedition 316 Site C0006" [Expedition 316 Scientists, 2009b] and "Expedition 316 Site C0007" [Expedition 316 Scientists, 2009c] chapters).

\section{Specimen preparation}

The whole-round samples were capped and taped in their plastic core liners on board the D/V Chikyu, sealed with wet sponges in aluminum vacuum bags to prevent moisture loss, and stored at $4^{\circ} \mathrm{C}$ until immediately prior to trimming. To extract each specimen, the plastic core liner was cut lengthwise along two lines $180^{\circ}$ apart using a hacksaw. The core liner was then removed to extrude the sample. Cylindrical specimens for permeability tests in the vertical 
(along-core) direction were trimmed using a wire saw and soil lathe. Specimen length after trimming was $\sim 4.4-5.9 \mathrm{~cm}$ and averaged $5.3 \mathrm{~cm}$ (Table T1). Specimen diameter was $\sim 3.4-4.1 \mathrm{~cm}$ and averaged $3.8 \mathrm{~cm}$. These dimensions were measured at several points using a caliper to a resolution of $0.03 \mathrm{~cm}$ and averaged to obtain the values used for subsequent calculations. Specimens for tests in the horizontal (crosscore) direction were trimmed from material immediately below the specimen for vertical (along-core) testing. These specimens were trimmed perpendicular to the core axis. Bedding dip with respect to the core axis was not taken into account during trimming.

Initial porosity was calculated from gravimetric water content of the specimen trimmings by assuming $100 \%$ pore water saturation. Values of specific gravity of the mineral solids have been imported from shipboard measurements of the closest adjacent specimen (see the "Expedition 316 Site C0006" [Expedition 316 Scientists, 2009b] and "Expedition 316 Site C0007" [Expedition 316 Scientists, 2009c] chapters). Gravimetric water content of the specimen trimmings was determined by measuring the ratio of the mass of water to the mass of mineral solids determined by oven-drying the trimmings at $105^{\circ} \mathrm{C}$ until constant mass was reached (generally within $24 \mathrm{~h}$ ) in accordance with shipboard measurement protocols (see "Expedition 316 methods" chapter [Expedition 316 Scientists, 2009a]). A correction for salt content as a percentage of the total dry weight was applied for all calculations of gravimetric water content and porosity, using

$$
W_{\mathrm{c}}=\left(M_{\mathrm{t}}-M_{\mathrm{d}}\right) /\left(M_{\mathrm{d}}-r M_{\mathrm{t}}\right),
$$

where

$W_{\mathrm{c}}=$ corrected dry weight,

$M_{\mathrm{t}}=$ total mass of the saturated specimen,

$M_{\mathrm{d}}=$ mass of the dried specimen, and

$r \quad=$ salinity (per mil).

For salt corrections on pretest trimmings, we assumed an average interstitial salinity value of 35\%o, and for post-test trimmings, we picked a value of $25 \%$ to match the concentration of the simulated seawater that was used to saturate specimens during the tests. Additional information in Table T1 includes Skempton's B-value to assess specimen saturation after backpressuring (see subsequent discussion), shipboard values of porosity and water content, and the post-test values of water content and porosity calculated from oven-dried trimmings after the specimens had been consolidated to $\sim 0.55$ MPa effective stress.

\section{Constant-flow apparatus}

Constant-flow, flow-through permeability tests were used to determine hydraulic conductivity in the vertical and horizontal core directions. A withdrawal-infuse syringe pump (KDS Scientific, Model 260) was used to simultaneously inject and extract pore fluid from the top and bottom of the specimen. The system consists of an acrylic confining cell to contain the specimen and provide isotropic effective confining stress, a constant flow syringe pump, one differential pressure transducer to measure hydraulic head difference between the specimen top cap and bottom cap, and an air/water interface panel for regulating the confining fluid pressure and pore fluid backpressure (Fig. F3). Signals from the differential pressure transducer are acquired to obtain hydraulic head difference through the specimen at a precision of $\pm 1 \mathrm{~cm} \mathrm{H}_{2} \mathrm{O}$ over a range spanning $\pm 1000 \mathrm{~cm} \mathrm{H}_{2} \mathrm{O}$. A digital interface is used for readout and storage of values of effective isotropic confining stress $\left(\sigma^{\prime}\right)$, hydraulic head difference $(\Delta h)$, and time duration measurements made during each test run. The flow pump holds two syringes (Hamilton GasTight Series 1000) and has the capability to cycle continuously back and forth in a push-pull action. As one syringe is infusing pore fluid into the specimen the other withdraws an equal volume of fluid from the other end of the specimen at the same rate. At the end of the set volume the direction is automatically reversed and the next cycle begins. With the use of three-way valves, the pump can empty and refill syringes for a continuous dispense. Volumetric flow rate $(Q)$ for the series of tests described here ranged from a minimum of $7.0 \times 10^{-5} \mathrm{~cm}^{3} / \mathrm{min}$ to a maximum of $8.0 \times 10^{-3} \mathrm{~cm}^{3} / \mathrm{min}$.

\section{Backpressure saturation}

Prior to testing, all permeant lines and porous stones were saturated with simulated seawater $(25 \mathrm{~g} \mathrm{NaCl}$ to $1 \mathrm{~L}$ tap water). A specimen was placed on the pedestal, the top cap was applied, and a latex membrane was placed on the specimen using a vacuum membrane expander. The confining chamber was then sealed and the cell was filled with tap water. Saturation of the specimen was achieved by ramping pore fluid backpressure to $0.48 \mathrm{MPa}$ (70 psi) using the panel board (air/water interface) while also ramping the confining pressure to maintain an effective isotropic confining stress of $0.034 \mathrm{MPa}$ (5 psi). Elevated backpressure was maintained for at least $24 \mathrm{~h}$. Saturation of the specimen was checked by increasing the confining pressure $(\sigma)$ to $0.55 \mathrm{MPa}(80 \mathrm{psi})$ and measuring the corresponding pore pressure $(u)$ response, which yields Skempton's $B$-value $(B=\Delta u / \Delta \sigma)$. 
Specimens were considered saturated if B $\geq 0.95$ (Table T1). Once saturation was achieved, the cell pressure was increased to consolidate the specimen at an isotropic effective stress of $0.55 \mathrm{MPa}$. Pore water was allowed to drain during consolidation from both the top and bottom of the specimen by opening the top and bottom valves on the confining cell system. The volume of pore water expelled was measured using the backpressure pipette and monitored for equilibrium to calculate the corresponding volume change of the specimen.

\section{Constant-flow permeation}

Constant-flow tests were performed for each of the 21 specimens (11 trimmed vertically, or parallel to the core axis, and 10 trimmed horizontally, or perpendicular to the core axis) at $0.55 \mathrm{MPa}$ (80 psi). Tests at this effective stress were run using four flow rates; two tests were conducted with a top-to-bottom flow direction (denoted subsequently as a negative flow value) and two tests were conducted with a bottom-to-top flow direction (denoted as a positive flow value) to obtain replicate permeability values (Fig. F4). Transient response from the differential pressure transducer was monitored for steady-state head difference $\left(\Delta h_{s}\right)$. Values of applied discharge velocity $(v)$ and steady-state hydraulic gradient $\left(i_{s}\right)$ were plotted to assess consistency among the four test runs and linearity in their relation (see the "Appendix"). Coefficient of determination $\left(R^{2}\right)$ calculated by leastsquared linear regression of these relations were not less than 0.9835, indicating good repeatability among the four flow tests conducted at each flow rate and the applicability of Darcy's law (Equation 2) for calculating hydraulic conductivity.

\section{Data analysis}

Hydraulic conductivity $(\mathrm{cm} / \mathrm{s})$ was calculated for each specimen using Darcy's law

$$
Q=K i_{s} A=K\left(\Delta h_{s} / \Delta L\right) A,
$$

where

$Q=$ applied volumetric flow rate $\left(\mathrm{cm}^{3} / \mathrm{s}\right)$,

$i_{\mathrm{s}}=$ steady-state hydraulic gradient equal to the ratio of the steady-state head difference $\left(\Delta h_{\mathrm{s}}\right)$ to the length over which that head difference occurs $(\Delta L)$ (taken as the initial height of the specimen), and

$A=$ cross-sectional flow area $\left(\mathrm{cm}^{2}\right.$; taken as the initial specimen area).

Corresponding discharge velocity is $v=Q / A$. Hydraulic conductivity values $(K=\mathrm{m} / \mathrm{s})$ were converted to intrinsic permeability $\left(k=\mathrm{m}^{2}\right)$ values using

$$
k=(K \mu) /(\rho g)
$$

where

$$
\begin{aligned}
& \mu=\text { viscosity of permeant }(0.001 \mathrm{~Pa} \cdot \mathrm{s}), \\
& \rho=\text { density of permeant }\left(1027 \mathrm{~kg} / \mathrm{m}^{3}\right), \text { and } \\
& g=\text { gravitational acceleration }\left(9.81 \mathrm{~m} / \mathrm{s}^{2}\right) .
\end{aligned}
$$

\section{Grain fabric imaging}

Specimens for grain fabric imaging were cut from the whole-round samples while trimming cylinders for the flow-through tests using a razor blade at vertical orientation and horizontal orientation relative to the axis of the cylindrical samples (Fig. F5). Grain fabric of wet, uncoated, and unfixed specimens was imaged using an FEI Quanta 600 FEG scanning electron microscope (SEM). The instrument operates in environmental mode (ESEM) at $30 \mathrm{kV}$, with the specimen chamber pressure set at $700 \mathrm{~Pa}$. Water vapor $(\sim 98 \%$ humidity) from a built-in reservoir keeps the specimen from losing moisture. The temperature of the cooling stage was set to $2^{\circ} \mathrm{C}$. The specimens were imaged with a gaseous backscattered electron detector, spot 3.0 at a working distance of $\sim 10 \mathrm{~mm}$. This combination generates an imaging resolution of $\sim 4 \mathrm{~nm}$, and the dimensions of the field of view are $\sim 145 \times$ $130 \mu \mathrm{m}$ with $2000 \times$ magnification. Specimens were placed in the holder on the stage with the imaged surface facing upward. "Center stage" and "Tilt" commands of the ESEM controlling software were used to manually adjust the imaging face to an orientation as close to perpendicular as possible to the imaging beam. All the image files were saved with color gray mode in TIF format (Fig. F6A).

Digital images were processed using software known as ImageJ (available at rsbweb.nih.gov/ij/index.html). Our processing steps were the following:

1. Contrast enhancement by linear stretching of the gray-level histogram in order to use 256 gray level values;

2. Median filter by moving each pixel value to the median values of nine closest pixels (to reduce noise);

3. Mean filter by replacing each pixel with the neighborhood mean. The size of the neighborhood is specified by entering its radius in the dialog box (to preserve subtle details);

4. Median hybrid filter by moving each pixel to the median values of the middle horizontal 3 pixels, center vertical 3 pixels, and center pixel of those 9 closest pixels (to reduce noise while preserving linear features);

5. Threshold adjustment by picking up one point of gray-level histogram (to select objects);

6. Make binary to transform the gray image to white and black image (e.g., Fig. F6B); 
7. Overlap the image onto the original image and set its alpha value (transparency) to 60\% in CorelDraw 11 software (Fig. F6C) and then separate objects that touch by manual adjustment with eraser tool (Fig. F6D);

8. Median filter with ImageJ to remove objects $<9$ pixels in size (because measurements on small objects are mostly biased);

9. Fill the holes on the objects; and

10. Measure automatically to obtain the long-axis and short-axis dimensions and long-axis orientation of an object.

The software can automatically determine the long or short axis (apparent dimensions) of the objects in the two-dimensional image. The results are automatically saved in a text file after the measurement.

\section{Characterization of microfabric anisotropy}

Grain fabric was characterized statistically using rose diagrams to depict orientations of the apparent long particle axes. In petrography, SEM, and transmission electron microscopy studies, most investigators measure between 100 and 500 grains per thin or ultrathin section (Krumbein, 1935; Friedman, 1958; van der Plas, 1962; Griffiths, 1967; Chiou et al., 1991). We generally counted between 200 and 500 grains (Table T2). Each particle orientation (apparent long axis) was assigned to an angle between $0^{\circ}$ and $180^{\circ}$. For the vertical section, the core axis is oriented at $90^{\circ}$. Rose diagrams were constructed using Rozeta software (www.softpedia.com/get/Science-CAD/ Rozeta.shtml). This software automatically counts the number of particles according to their orientation and combines data into bins of $10^{\circ}$ intervals. In addition to the rose diagram, the number of values in each bin was summed and normalized to $100 \%$. Cumulative frequency curves of the normalized bin percentages were constructed to show the distribution of grain orientation and calculate graphical statistics (Chiou et al., 1991).

Various statistical methods can be used to characterize the degree of preferred grain orientation, such as the formulas of Folk and Ward (1957), Martínez-Nistal et al. (1999), and Zaniewski and van der Meer (2005). The Folk and Ward (1957) formula was developed originally to graphically compute values of sorting (standard deviation) for grain size data. The equivalent equation for standard deviation of grain orientation $(d)$ is

$$
d=\left[\left(\phi_{84}-\phi_{16}\right) / 4\right]+\left[\left(\phi_{95}-\phi_{5}\right) / 6.6\right],
$$

where $\phi_{84}, \phi_{16}, \phi_{95}$, and $\phi_{5}$ represent the angle of orientation (in degrees) at the 84th, 16th, 95th, and 5th percentiles, respectively, on the cumulative frequency curve. This graphic technique avoids the laborious calculations required by moment statistics (Chiou et al., 1991). If the fabric of sediment shows strong preferred orientation, then the sorting of orientation angles will be more tightly clustered and the cumulative frequency curve will be steeper around the median. Numerically, the largest value of $d$ is $72.3^{\circ}$ (i.e., a case in which $\phi_{16}$ and $\phi_{5}=0^{\circ}$ and $\phi_{84}$ and $\left.\phi_{95}=180^{\circ}\right)$. We normalized each standard deviation to this maximum $d$ value by calculating the "index of microfabric orientation" (i) as

$$
i=1-(d / 72.3) \text {. }
$$

The closer the value of $i$ is to 1 , the more the particles are aligned in a preferred direction. For a highly random arrangement of particles, the cumulative curve generally has a slope $<0.75$ near the median, the standard deviation of orientation is $>35^{\circ}$, and the index of orientation is $<0.51$. For well-oriented clay particles, the slope of the cumulative curve is generally $>1.00$ near the median, the standard deviation of grain orientation is $<25^{\circ}$, and the index of microfabric orientation is $>0.65$ (Yue et al., submitted). To compare $i$ values from imaging surfaces that were cut parallel and perpendicular to the core axis, we calculated the orientation index ratio $\left(i_{h} / i_{v}\right)$.

\section{Results}

Table T1 summarizes the values of gravimetric water content and porosity for trimmings measured before and after each constant flow-through test. The table also indicates average height and diameter of each specimen and backpressure saturation. The values of gravimetric water content and porosity differ from shipboard measurements but in an inconsistent manner. In cases where water content appears to decrease relative to shipboard values, these discrepancies may be due to partial loss of moisture during shipment and storage of the whole-round specimens. For one specimen (Sample 316-C0006E-7H-2, $117 \mathrm{~cm}$ ), the value of porosity after the flow-through test is significantly greater than the value of porosity before the test. This could be a result of operator error and/or expansion of water-filled microcracks after the specimen was released from the confining pressure. It is important to note that the same specimen could not be trimmed for a test in the horizontal flow direction because of excessive fracturing. We consider the vertical test results to be unreliable for Sample 316-C0006E-7H-2, $117 \mathrm{~cm}$. The data have been included in Table T2 but were omitted from the illustrations. 
Table T2 summarizes the average values of vertical $\left(k_{\mathrm{v}}\right)$ and horizontal $\left(k_{\mathrm{h}}\right)$ permeability and the corresponding $k_{\mathrm{h}} / k_{\mathrm{v}}$ ratio for each specimen. Volumetric flow rate $(Q)$, discharge velocity $(v)$, steady-state head loss $\left(\Delta h_{\mathrm{s}}\right)$, steady-state hydraulic gradient $\left(i_{\mathrm{s}}\right)$, hydraulic conductivity $(K)$, and intrinsic permeability $(k)$ from four test runs conducted for each specimen at $0.55 \mathrm{MPa}(80 \mathrm{psi})$ effective stress $\left(\sigma^{\prime}\right)$ are summarized in Table T3.

At Site C0006, the highest value of vertical hydraulic conductivity is $1.60 \times 10^{-6} \mathrm{~cm} / \mathrm{s}$ with corresponding intrinsic permeability of $1.63 \times 10^{-15} \mathrm{~m}^{2}$. The lowest value of vertical hydraulic conductivity is $2.63 \times 10^{-10}$ $\mathrm{cm} / \mathrm{s}$ with intrinsic permeability equal to $2.68 \times 10^{-19}$ $\mathrm{m}^{2}$. The highest value of horizontal hydraulic conductivity is $2.07 \times 10^{-6} \mathrm{~cm} / \mathrm{s}$ with intrinsic permeability equal to $2.11 \times 10^{-15} \mathrm{~m}^{2}$, and the lowest value of horizontal hydraulic conductivity is $3.25 \times 10^{-10} \mathrm{~cm} / \mathrm{s}$ with intrinsic permeability equal to $3.32 \times 10^{-19} \mathrm{~m}^{2}$. The $k_{\mathrm{h}} / k_{\mathrm{v}}$ permeability ratio is generally $>1.0$, ranging from 0.02 to 19.9 and averaging 4.27.

At Site $\mathrm{C0007}$ the highest value of vertical hydraulic conductivity is $1.24 \times 10^{-9} \mathrm{~cm} / \mathrm{s}$ with corresponding intrinsic permeability of $1.27 \times 10^{-18} \mathrm{~m}^{2}$. The lowest value of vertical hydraulic conductivity is $9.54 \times 10^{-10}$ $\mathrm{cm} / \mathrm{s}$ with intrinsic permeability equal to $9.73 \times 10^{-19} \mathrm{~m}^{2}$. The highest value of horizontal hydraulic conductivity is $1.15 \times 10^{-9} \mathrm{~cm} / \mathrm{s}$ with intrinsic permeability equal to $1.17 \times 10^{-18} \mathrm{~m}^{2}$, and the lowest value of horizontal hydraulic conductivity is $8.09 \times 10^{-10} \mathrm{~cm} / \mathrm{s}$ with intrinsic permeability equal to $8.26 \times 10^{-19} \mathrm{~m}^{2}$. The $k_{\mathrm{h}} / k_{\mathrm{v}}$ ratio for Site C0007 ranges from 1.21 to 0.65 with a mean value 0.93 .

Figure F7 shows how vertical and horizontal permeability values, together with the corresponding $k_{\mathrm{h}} / k_{\mathrm{v}}$ ratio, change as the sampling depth increases. Values of vertical and horizontal permeability both decrease with increasing depth except for one anomalous sample that was taken from $300 \mathrm{~m}$ core depth below (CSF) (Sample 316-C0006E-39X-3, $48 \mathrm{~cm}$ ). The anisotropy ratio for permeability shows a modest decrease with depth and an anomalous result at $150 \mathrm{~m}$ CSF (Sample 316-C0006E-22X-6, $5 \mathrm{~cm}$ ).

Figure F8 displays the relation between permeability and porosity for tests conducted at an effective confining stress of $0.55 \mathrm{MPa}$. Porosity values were calculated from the post-test water content measurements (Table T1). The data do not show a systematic trend in the relation between porosity and permeability. In fact, for samples with porosity values between $35 \%$ and $45 \%$, values of intrinsic permeability change by four orders of magnitude. There is an apparent segregation of values between the two sites. We note a shift toward higher porosities and lower permeabilities at Site C0007, although the number of samples tested is not large enough to demonstrate a definitive statistical difference.

Figure F9 shows all of the specimen images that were taken by ESEM. Figure F10 shows rose diagrams of particle orientation and corresponding values for the standard deviation and index of orientation. These values are also tabulated in Table T4. The standard deviation for grain orientation ranges from $30.5^{\circ}$ to $56.5^{\circ}$, and the index of orientation ranges from 0.18 to 0.58 . Figure F11 shows all corresponding cumulative frequency curves for particle orientation. With one exception, the standard deviations of orientation and the indexes of orientation are consistent with highly random arrangements of particles. Indexes of orientation are typically greater for the vertical section (parallel to core axis) than for the horizontal section (perpendicular to core axis). No clearly defined relation is apparent between the average indexes of orientation and depth of burial. Interpretation of these results, however, needs to take the dip of bedding into account, and for many samples the beds dip at angles $>30^{\circ}$ (Fig. F2; Table T2). For example, even if beds of mudstone display a strong bedding-parallel fabric (e.g., shale fissility) but dip close to $45^{\circ}$, we would not expect to see significant differences between the SEM images for horizontal and vertical sections.

Figure F12A illustrates the relation between permeability anisotropy and the microfabric orientation index for the horizontal section. Figure F12B shows how the anisotropy of permeability changes as a function of the orientation index ratio. Ratios of $i_{\mathrm{h}} / i_{\mathrm{v}}$ range from $\sim 0.5$ to 1.3 . For the majority of specimens, microfabric on the vertical cut face shows better preferred orientation than microfabric on the horizontal cut $\left(i_{\mathrm{h}}<i_{\mathrm{v}}\right)$. Samples with significant increases in the anisotropy of permeability $\left(k_{\mathrm{h}} / k_{\mathrm{v}}>1\right)$ also show significant improvements of preferred orientation on the vertical cut face. This sensitivity of permeability to changes in grain fabric is to be expected as a weak fissility begins to develop with progressive compaction of the mudstone.

\section{Acknowledgments}

Samples were provided by the Integrated Ocean Drilling Program (IODP). We thank the crew, technicians, and shipboard scientists aboard the Chikyu for their assistance in acquisition of samples during Expedition 316. The study was supported by Turkish Petroleum Cooperation (scholarship to M.K. Ekinci), the National Science Foundation (grant OCE0751819), and the Consortium for Ocean Leadership 
(grants T315A58, T315B58, and T315C58). Louis Ross provided expert guidance with ESEM imaging. We thank S. Bourlange for his review of the manuscript.

\section{References}

Anandarajah, A., and Kuganenthira, N., 1995. Some aspects of fabric anisotropy of soil. Géotechnique, 45(1):69-81. doi:10.1680/geot.1995.45.1.69

Aplin, A.C., Matenaar, I.F., McCarty, D.K., and van der Pluijm, B.A., 2006. Influence of mechanical compaction and clay mineral diagenesis on the microfabric and pore-scale properties of deep-water Gulf of Mexico mudstones. Clays Clay Miner., 54(4):500-514. doi:10.1346/ CCMN.2006.0540411

Bennett, R.H., Fischer, K.M., Lavoie, D.L., Bryant, W.R., and Rezak, R., 1989. Porometry and fabric of marine clay and carbonate sediments: determinants of permeability. Mar. Geol., 89(1-2):127-152. doi:10.1016/00253227(89)90030-3

Bennett, R.H., O'Brien, N.R., and Hulbert, M.H., 1991. Determinants of clay and shale microfabric signatures: processes and mechanisms. In Bennett, R.H., Bryant, W.R., and Hulbert, M.H. (Eds.), Microstructure of FineGrained Sediments: From Mud to Shale: New York (Springer-Verlag), 5-32.

Bolton, A.J., Maltman, A.J., and Fisher, Q., 2000. Anisotropic permeability and bimodal pore-size distributions of fine-grained marine sediments. Mar. Pet. Geol., 17(6):657-672. doi:10.1016/S0264-8172(00)00019-2

Carson, B., and Screaton, E.J., 1998. Fluid flow in accretionary prisms: evidence for focussed, time-variable discharge. Rev. Geophys., 36(3):329-351. doi:10.1029/ 97RG03633

Chiou, W.-A., Bennett, R.H., and Bryant, W.R., 1991. Quantification of clay fabric: a simple technique. In Bennett, R.H., Bryant, W.R., and Hulbert, M.H. (Eds.), Microstructure of Fine-Grained Sediments: From Mud to Shale: New York (Springer-Verlag), 379-387.

Clennell, M.B., Dewhurst, D.N., Brown, K.M., and Westbrook, G.K., 1999. Permeability anisotropy of consolidated clays. In Aplin, A.C., Fleet, A.J., and MacQuaker, J.H.S. (Eds.), Muds and Mudstones: Physical and Fluid-Flow Properties. Geol. Soc. Spec. Publ., 158(1):79-96. doi:10.1144/GSL.SP.1999.158.01.07

Delage, P., and Lefebvre, G., 1984. Study of the structure of a sensitive Champlain clay and its evolution during consolidation. Can. Geotech. J., 21(1):21-35. doi:10.1139/t84-003

Dewhurst, D.N., Yang, Y., and Aplin, A.C., 1999. Permeability and fluid flow in natural mudstones. In Aplin, A.C., Fleet, A.J., and MacQuaker, J.H.S. (Eds.), Muds and Mudstones: Physical and Fluid-Flow Properties. Geol. Soc. Spec. Publ., 158(1):23-43. doi:10.1144/

GSL.SP.1999.158.01.03

Expedition 316 Scientists, 2009a. Expedition 316 methods. In Kinoshita, M., Tobin, H., Ashi, J., Kimura, G., Lallemant, S., Screaton, E.J., Curewitz, D., Masago, H., Moe,
K.T., and the Expedition 314/315/316 Scientists, Proc. IODP, 314/315/316: Washington, DC (Integrated Ocean Drilling Program Management International, Inc.). doi:10.2204/iodp.proc.314315316.132.2009

Expedition 316 Scientists, 2009b. Expedition 316 Site C0006. In Kinoshita, M., Tobin, H., Ashi, J., Kimura, G., Lallemant, S., Screaton, E.J., Curewitz, D., Masago, H., Moe, K.T., and the Expedition 314/315/316 Scientists, Proc. IODP, 314/315/316: Washington, DC (Integrated Ocean Drilling Program Management International, Inc.). doi:10.2204/iodp.proc.314315316.134.2009

Expedition 316 Scientists, 2009c. Expedition 316 Site C0007. In Kinoshita, M., Tobin, H., Ashi, J., Kimura, G., Lallemant, S., Screaton, E.J., Curewitz, D., Masago, H., Moe, K.T., and the Expedition 314/315/316 Scientists, Proc. IODP, 314/315/316: Washington, DC (Integrated Ocean Drilling Program Management International, Inc.). doi:10.2204/iodp.proc.314315316.135.2009

Folk, R.L., and Ward, W.C., 1957. Brazos River bar [Texas]: a study in the significance of grain size parameters. $J$. Sediment. Res., 27(1):3-26. http://jsedres.sepmonline.org/cgi/content/abstract/27/1/3

Friedman, G.M., 1958. Determination of sieve-size distribution from thin-section data for sedimentary petrological studies. J. Geol., 66(4):349-416. doi:10.1086/ 626525

Gamage, K., and Screaton, E., 2006. Characterization of excess pore pressures at the toe of the Nankai accretionary complex, Ocean Drilling Program Sites 1173, 1174, and 808: results of one-dimensional modeling. J. Geophys. Res., [Solid Earth], 111:B04103. doi:10.1029/ 2004JB003572

Gamage, K., Screaton, E., Bekins, B., and Aiello, I., 2011. Permeability-porosity relationships of subduction zone sediments. Mar. Geol., 279(1-4):19-36. doi:10.1016/ j.margeo.2010.10.010

Griffiths, J.C., 1967. Scientific Method in Analysis of Sediments: New York (McGraw-Hill). doi:10.1126/science.159.3812.295

Kim, J.-W., Bryant, W.R., Watkins, J.S., and Tieh, T.T., 1999. Electron microscopic observations of shale diagenesis, offshore Louisiana, USA, Gulf of Mexico. Geo-Mar. Lett., 18(3):234-240. doi:10.1007/s003670050073

Krumbein, W.C., 1935. Thin-section mechanical analysis of indurated sediments. J. Geol., 43(5):482-496. doi:10.1086/624330

Martínez-Nistal, A., Veniale, F., Setti, M., and Cotecchia, F., 1999. A scanning electron microscopy image processing method for quantifying fabric orientation of clay geomaterials. Appl. Clay Sci., 14(4):235-243. doi:10.1016/ S0169-1317(98)00055-6

Mitchell, J.K., 1993. Fundamentals of Soil Behavior (2nd ed.): New York (Wiley).

Moon, C.F., and Hurst, C.W., 1984. Fabrics of muds and shales: an overview. In Stow, D.A.V., and Piper, D.J.W. (Eds.), Fine-Grained Sediments: Deep-Water Processes and Facies. Geol. Soc. Spec. Publ., 15(1):579-593.

doi:10.1144/GSL.SP.1984.015.01.36

Moore, G.F., Park, J.-O., Bangs, N.L., Gulick, S.P., Tobin, H.J., Nakamura, Y., Sato, S., Tsuji, T., Yoro, T., Tanaka, 
H., Uraki, S., Kido, Y., Sanada, Y., Kuramoto, S., and Taira, A., 2009. Structural and seismic stratigraphic framework of the NanTroSEIZE Stage 1 transect. In Kinoshita, M., Tobin, H., Ashi, J., Kimura, G., Lallemant, S., Screaton, E.J., Curewitz, D., Masago, H., Moe, K.T., and the Expedition 314/315/316 Scientists, Proc. IODP, 314/315/316: Washington, DC (Integrated Ocean Drilling Program Management International, Inc.). doi:10.2204/iodp.proc.314315316.102.2009

Moore, J.C., and Vrolijk, P., 1992. Fluids in accretionary prisms. Rev. Geophys., 30(2):113-135. doi:10.1029/ 92RG00201

Neuzil, C.E., 1994. How permeable are clays and shales? Water Resour. Res., 30(2):145-150. doi:10.1029/ 93WR02930

Olsen, H.W., 1960. Hydraulic flow through saturated clay. Clays Clay Miner., 9(1)131-161. doi:10.1346/ CCMN.1960.0090108

Saffer, D.M., and Bekins, B.A., 2002. Hydrologic controls on the morphology and mechanics of accretionary wedges. Geology, 30(3):271-274. doi:10.1130/00917613(2002)030<0271:HCOTMA >2.0.CO;2

Saffer, D.M., and Bekins, B.A., 2006. An evaluation of factors influencing pore pressure in accretionary complexes: implications for taper angle and wedge mechanics. J. Geophys. Res., [Solid Earth], 111(B4):B04101-B04121. doi:10.1029/2005JB003990

Schwartz, F.W., and Zhang, H., 2003. Fundamentals of Ground Water: New York (Wiley).

Screaton, E.J., Kimura, G., Curewitz, D., and the Expedition 316 Scientists, 2009a. Expedition 316 summary. In Kinoshita, M., Tobin, H., Ashi, J., Kimura, G., Lallemant, S., Screaton, E.J., Curewitz, D., Masago, H., Moe, K.T., and the Expedition 314/315/316 Scientists, Proc. IODP, 314/315/316: Washington, DC (Integrated Ocean Drilling Program Management International, Inc.). doi:10.2204/iodp.proc.314315316.131.2009

Screaton, E., Kimura, G., Curewitz, D., Moore, G., Fabbri, O., Fergusson, C., Girault, F., Goldsby, D., Harris, R.,
Inagaki, F., Jiang, T., Kitamura, Y., Knuth, M., Li, C.-F., Claesson Liljedahl, L., Louis, L., Milliken, K., Nicholson, U., Riedinger, N., Sakaguchi, A., Solomon, E., Strasser, M., Su, X., Tsutsumi, A., Yamaguchi, A., Ujiee, K., and Zhao, X., 2009b. Interactions between deformation and fluids in the frontal thrust region of the NanTroSEIZE transect offshore the Kii Peninsula, Japan: results from IODP Expedition 316 Sites C0006 and C0007. Geochem., Geophys., Geosyst., 10:Q0AD01-Q0AD14. doi:10.1029/ 2009GC002713

Sintubin, M., 1994. Clay fabrics in relation to the burial history of shales. Sedimentology, 41(6):1161-1169. doi:10.1111/j.1365-3091.1994.tb01447.x

van der Plas, L., 1962. Preliminary note on the granulometric analysis of sedimentary rocks. Sedimentology, 1(2):145-157. doi:10.1111/j.13653091.1962.tb00031.x

Yang, Y., and Aplin, A.C., 2007. Permeability and petrophysical properties of 30 natural mudstones. J. Geophys. Res., [Solid Earth], 112(B3):B03206-B03219. doi:10.1029/2005JB004243

Yue, L., Likos, W.J., Guo, J., and Underwood, M.B., submitted. Data report: permeability of mud(stone) samples from Site C0001, IODP Expedition 315, Nankai Trough: Stage 1 of NanTroSEIZE. In Kinoshita, M., Tobin, H., Ashi, J., Kimura, G., Lallemant, S., Screaton, E.J., Curewitz, D., Masago, H., Moe, K.T., and the Expedition 314/ 315/316 Scientists, Proc. IODP, 314/315/316: Washington, DC (Integrated Ocean Drilling Program Management International, Inc.).

Zaniewski, K., and Van Der Meer, J.J.M., 2005. Quantification of plasmic fabric through image analysis. Catena, 63(1):109-127. doi:10.1016/j.catena.2005.07.001

Initial receipt: 20 October 2010

Acceptance: 24 May 2011

Publication: 21 September 2011

MS 314315316-214 
Figure F1. Maps and seismic reflection profile showing locations of Sites C0006 and C0007 (from the "Expedition 316 summary" chapter [Screaton et al., 2009a]).
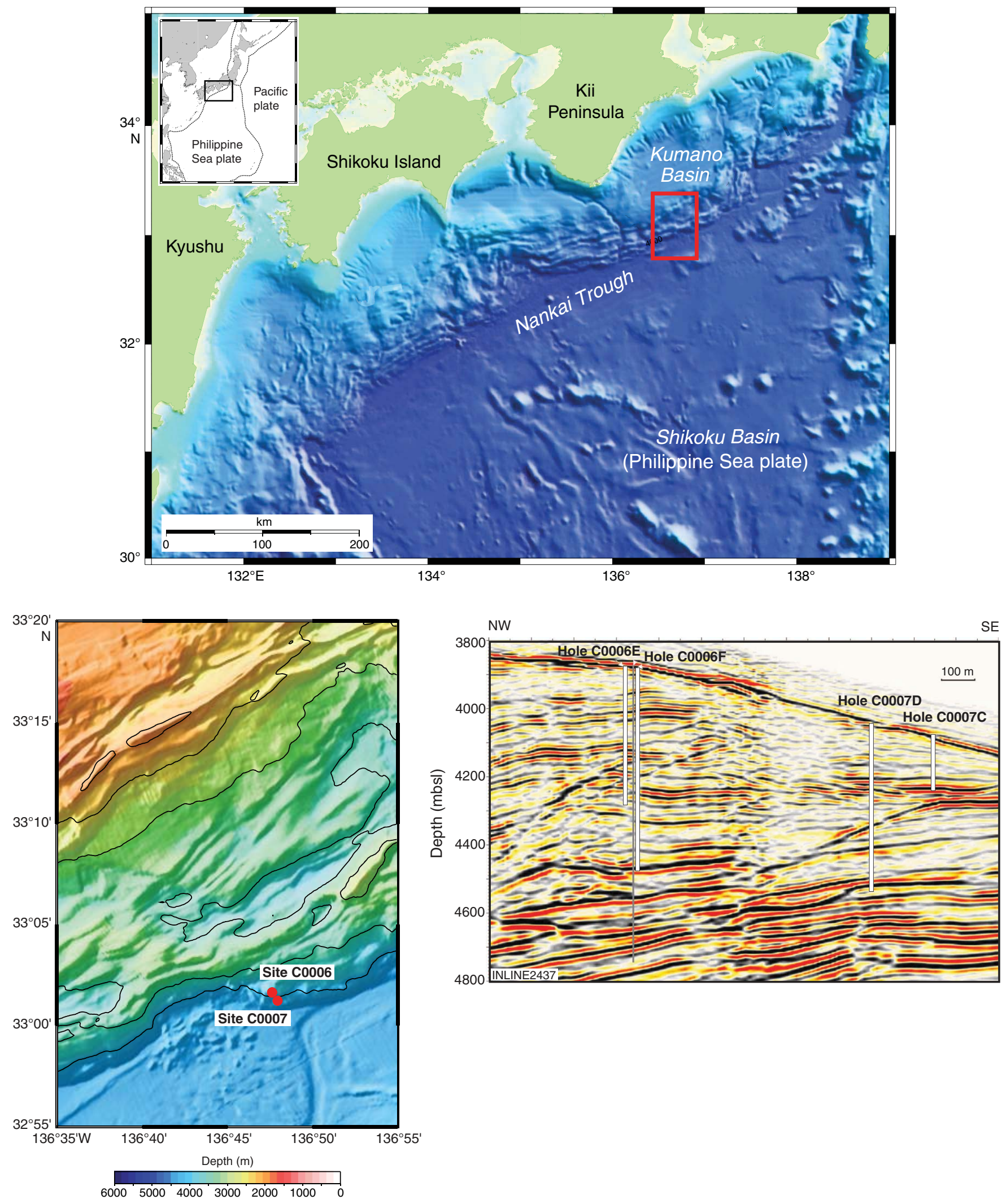
Figure F2. Stratigraphic columns for Sites C0006 and C0007 with positions of samples used for permeability tests. Bedding dips are for closest nearby intervals and taken from the "Expedition 316 Site C0006" and "Expedition 316 Site C0007" chapters (Expedition 316 Scientists, 2009b, 2009c).

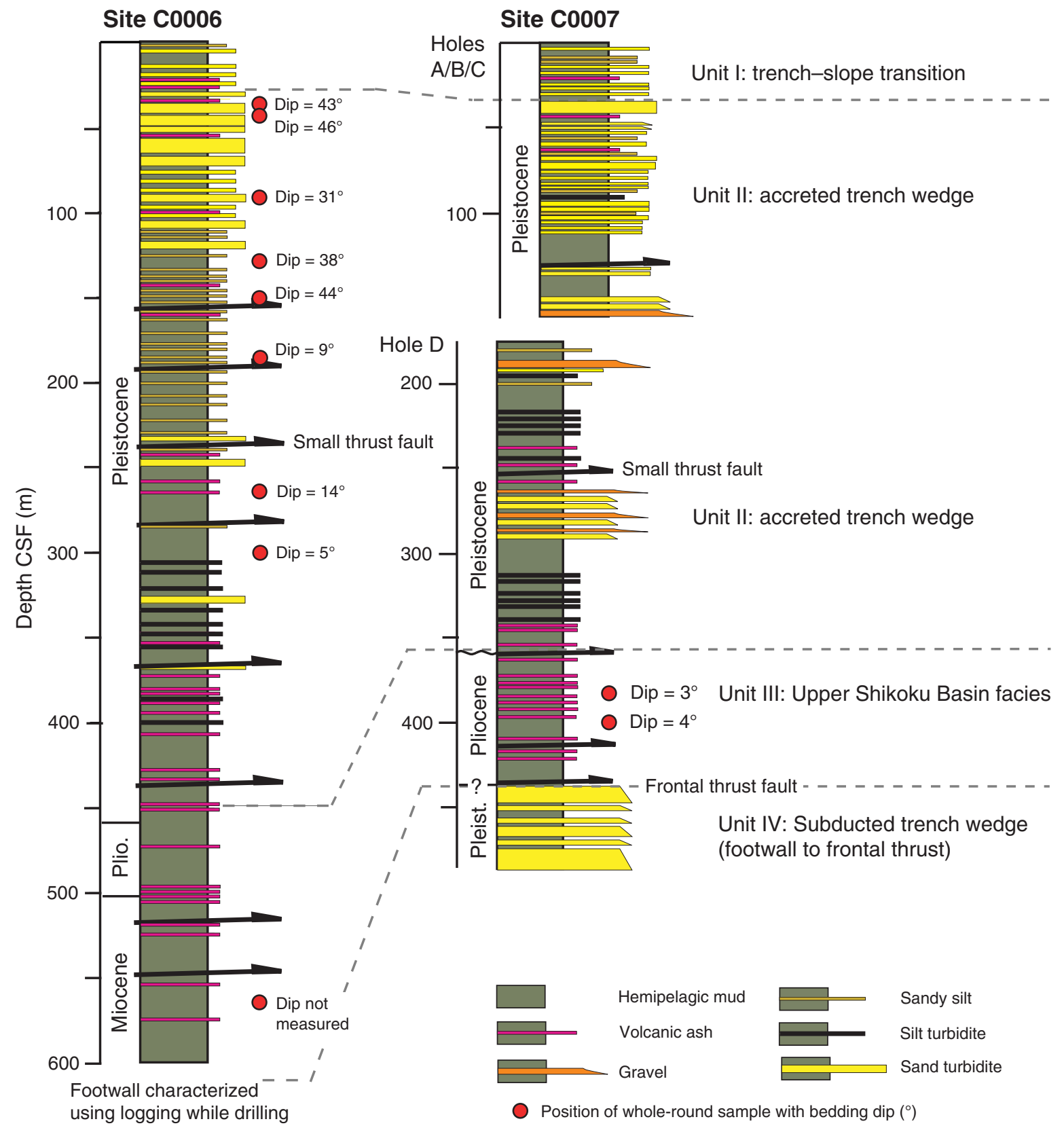


Figure F3. Schematic of constant-flow permeability testing system used for Expedition 316 samples at the University of Missouri (USA).

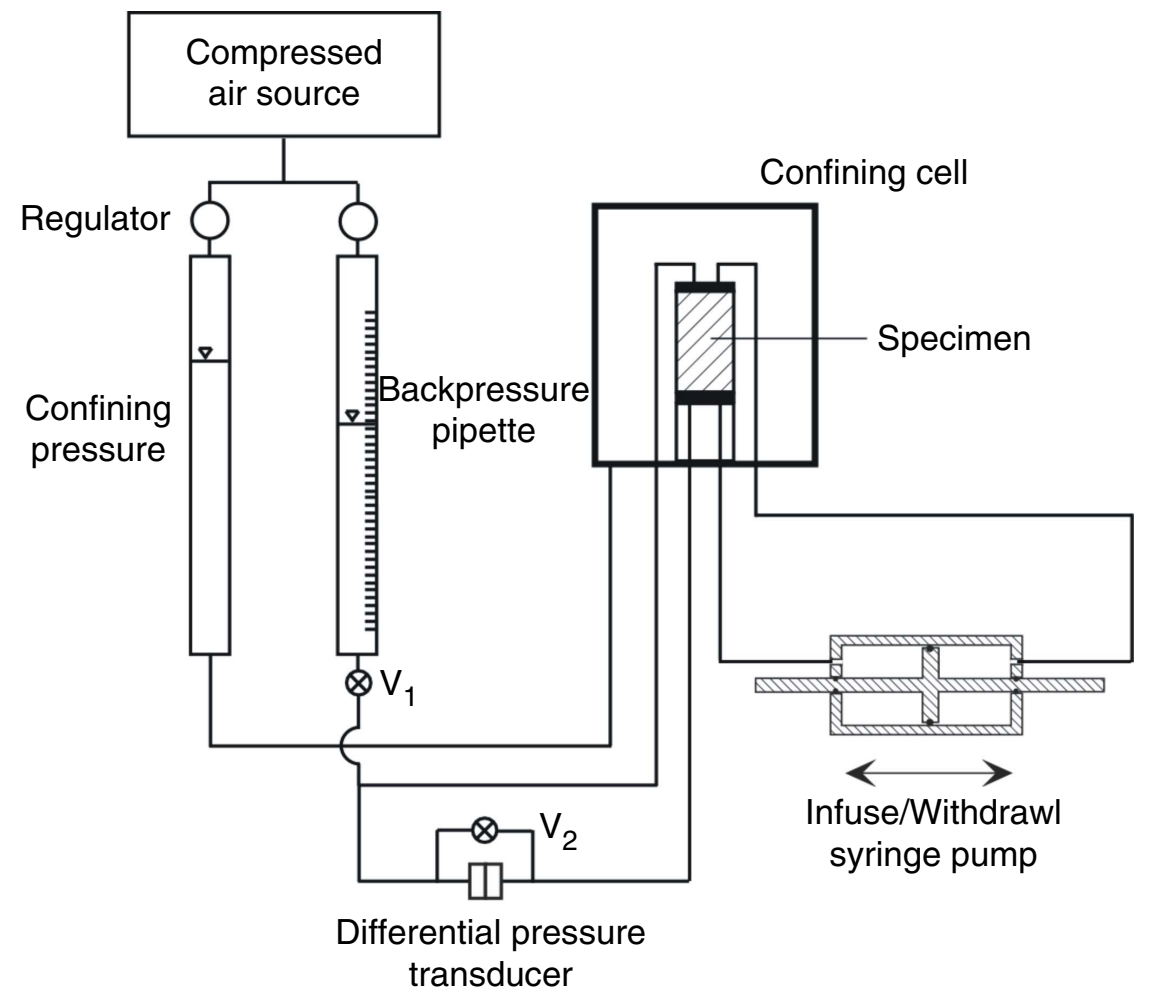


Figure F4. Plot of responses of transient head difference $\left(\Delta h_{s}\right)$ during flow-through testing. $Q=$ volumetric flow rate, $K=$ hydraulic conductivity.

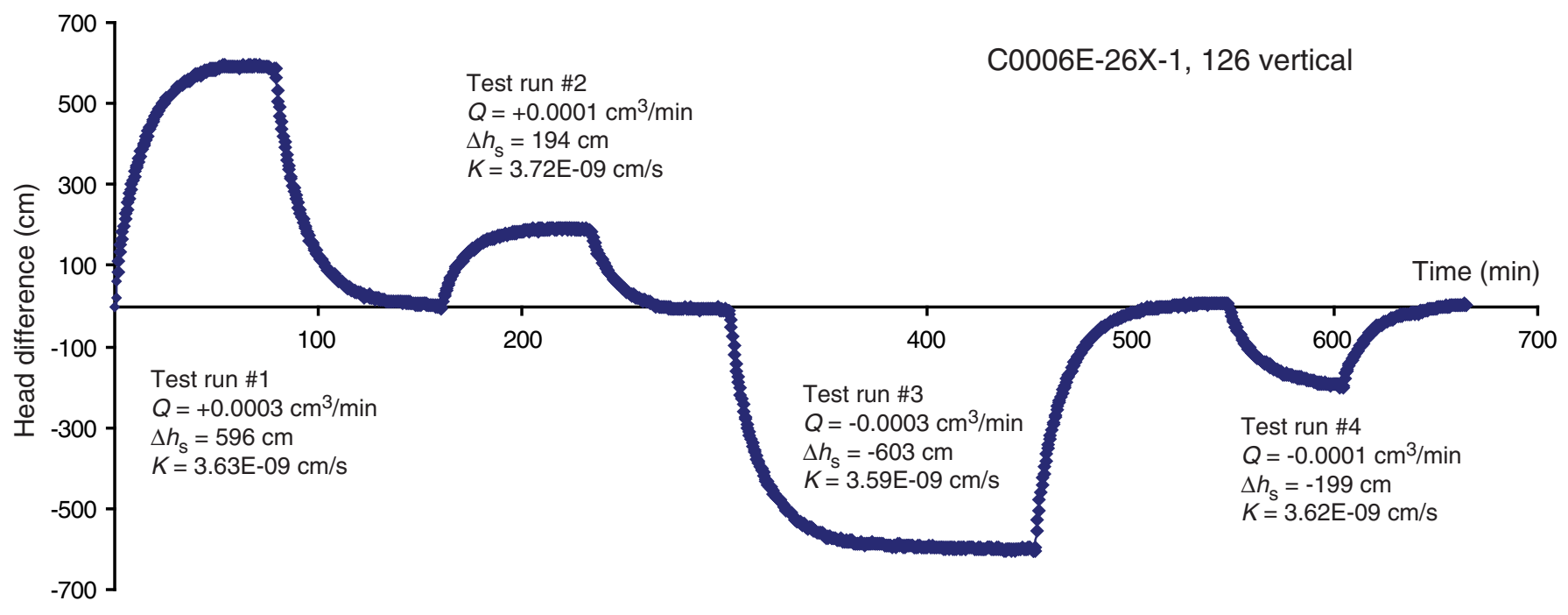


Figure F5. Diagram representing the horizontal and vertical section of core for imaging by environmental scanning electron microscope.

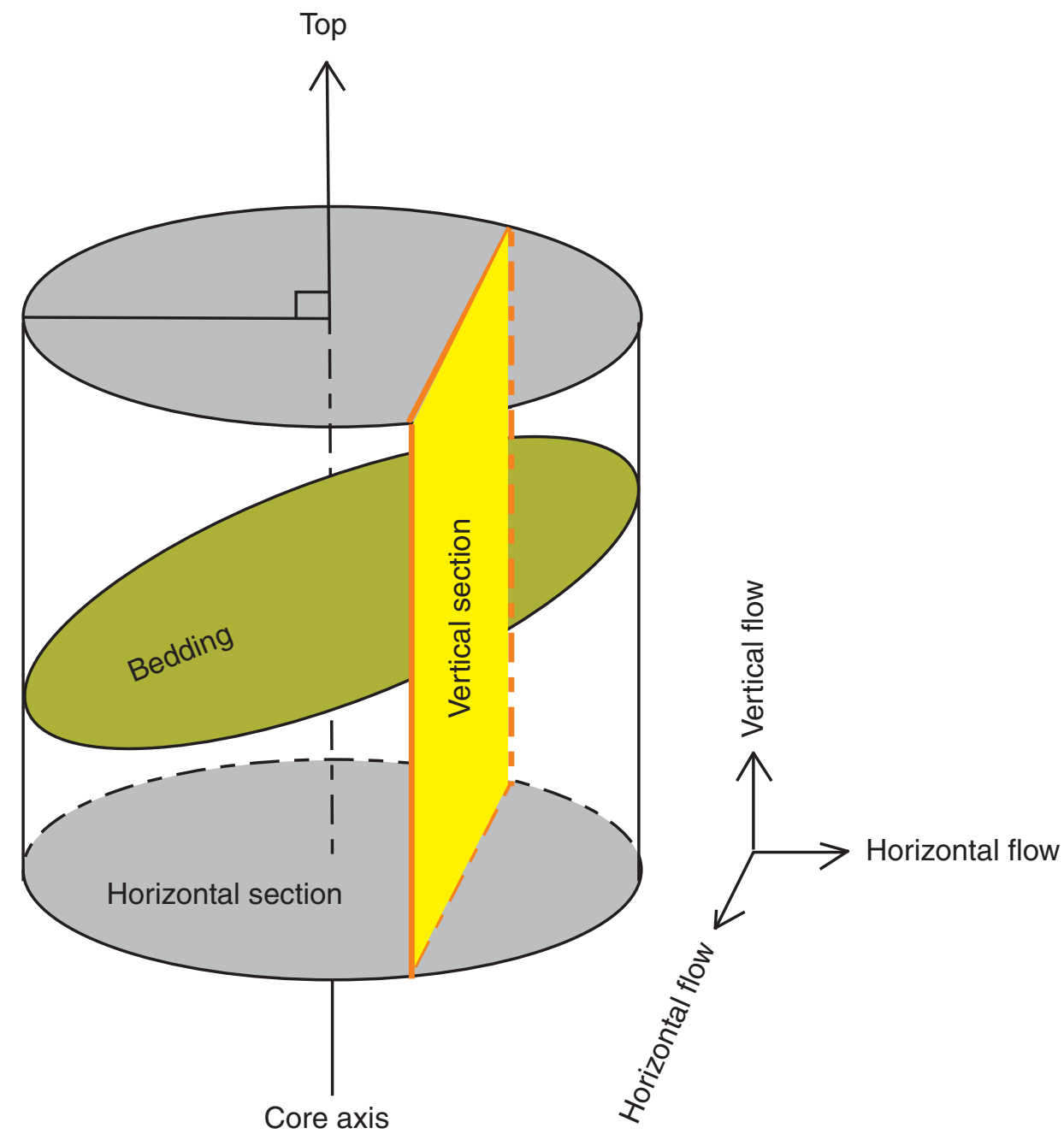


Figure F6. Illustrations of steps used during image analysis of microfabric (Sample 316-C0006E-5H-1, $128 \mathrm{~cm}$ ). A. Environmental scanning electron microscope image. B. Binary image obtained with ImageJ software. C. Binary image (transparency $=60 \%$ ) overlying the original image using CorelDraw software. D. Binary image after particle separation using the eraser tool in CorelDraw.
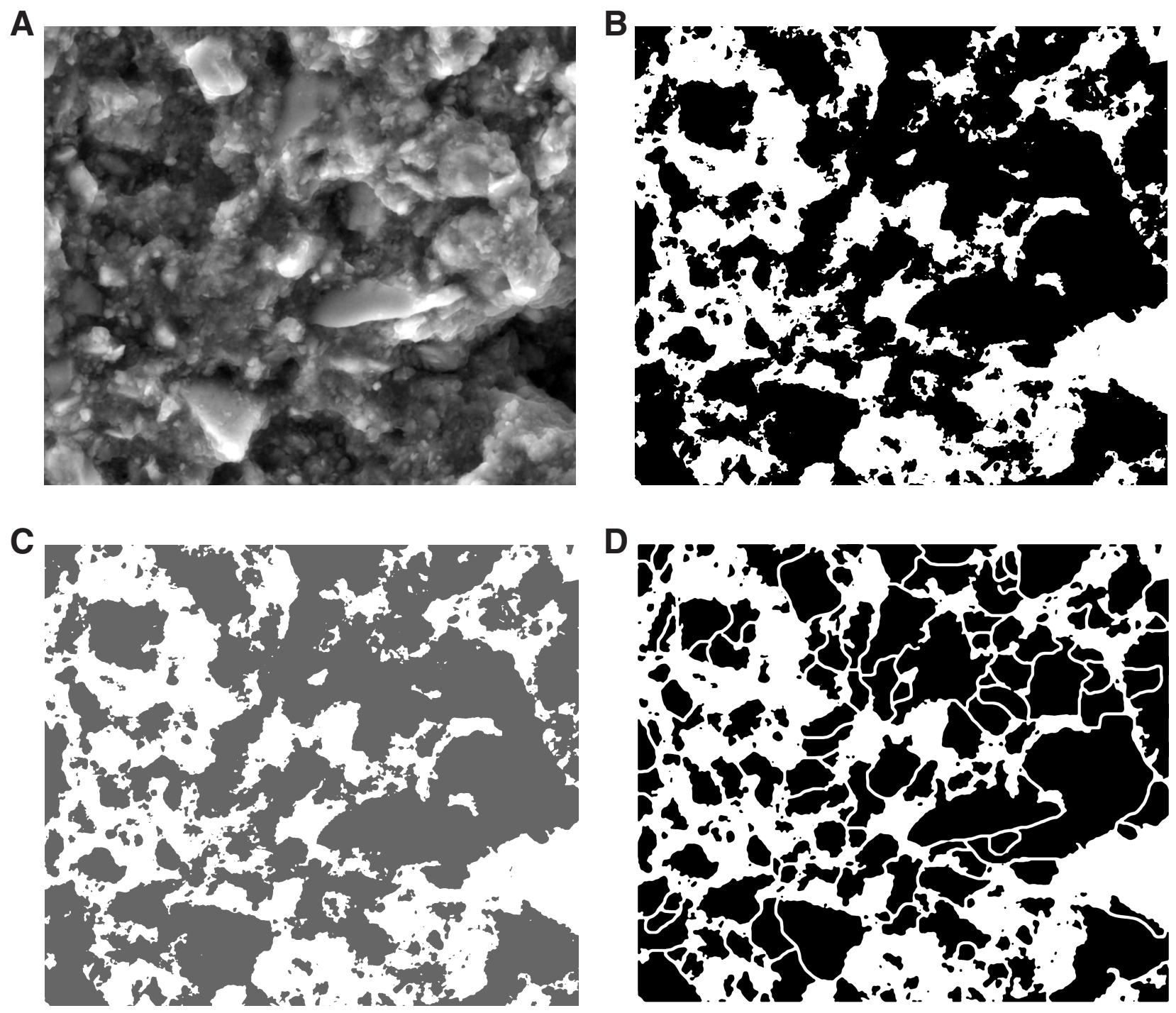
Figure F7. Plots of anisotropy ratio for intrinsic permeability (horizontal/vertical) and values of vertical and horizontal permeability, Sites C0006 and C0007. Permeability was measured at an effective stress of $0.55 \mathrm{MPa}$.

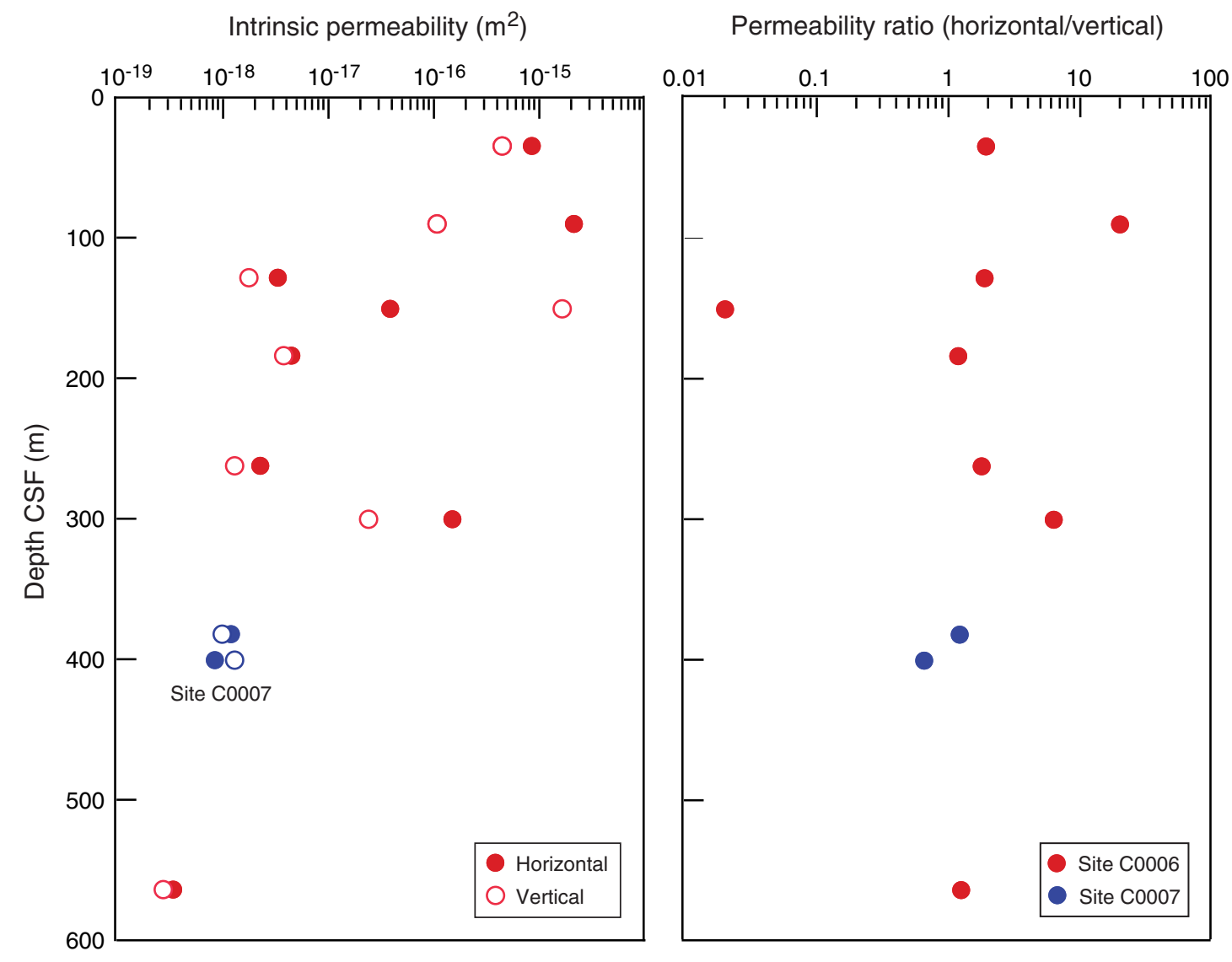


Figure F8. Plot of relation between intrinsic permeability and porosity for test specimens from Sites C0006 and C0007. Permeability was measured at an effective stress of $0.55 \mathrm{MPa}$. Porosity values are for post-test specimens.

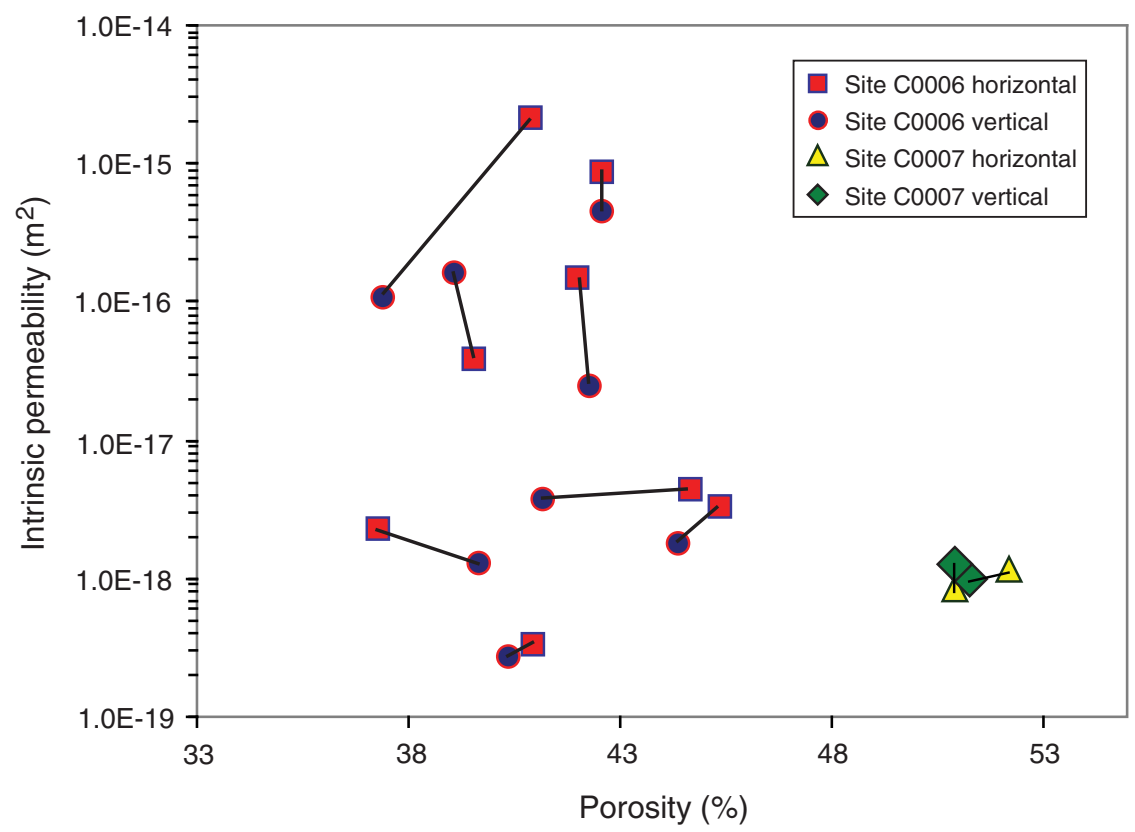


Figure F9. Environmental scanning electron microscope images for all specimens tested for permeability, Sites C0006 and C0007. Sections were cut parallel and perpendicular to core axis. See Figure F2 and Table T2 for bedding dips. (Continued on next two pages.)
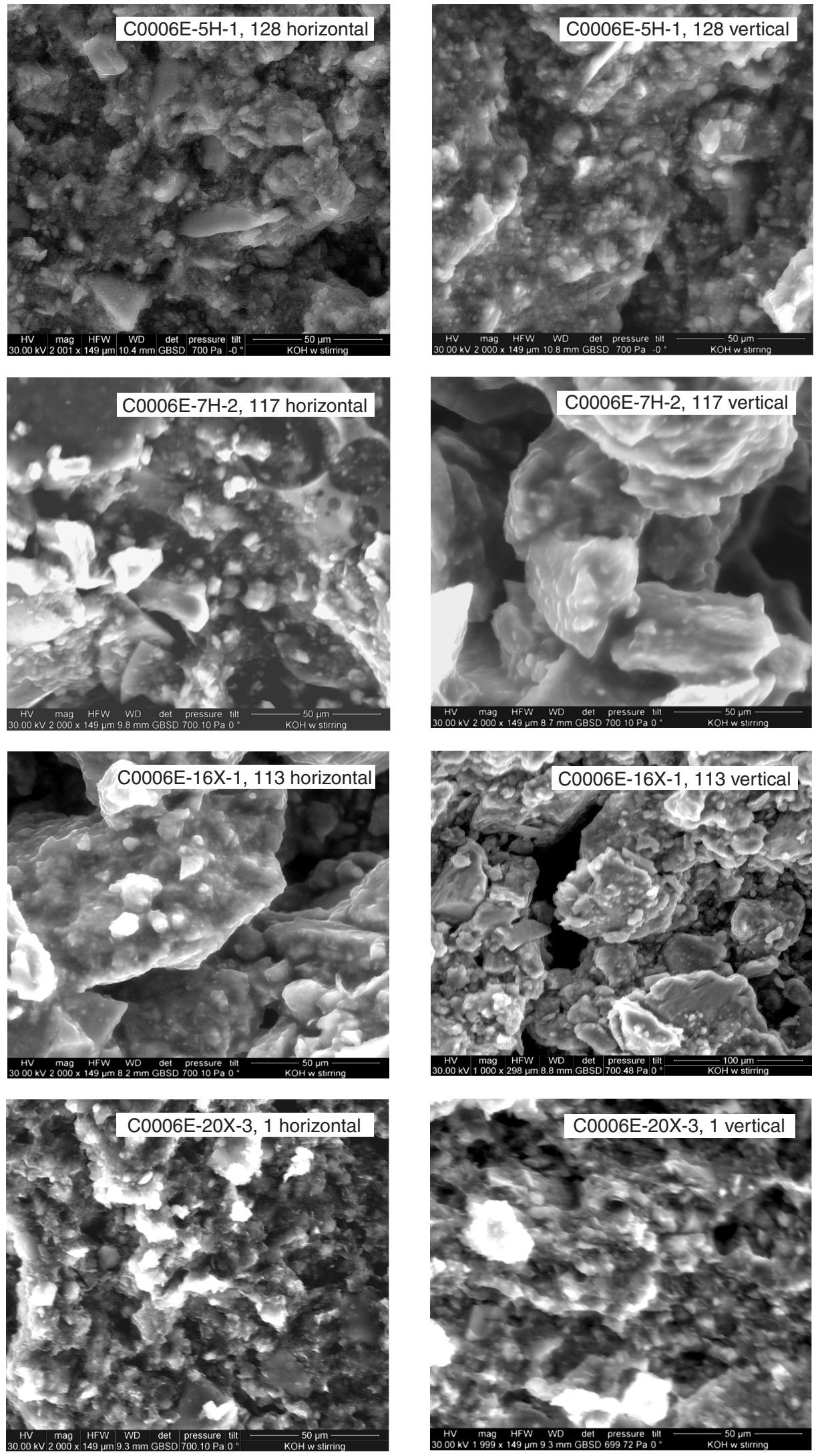
Figure F9 (continued). (Continued on next page.)
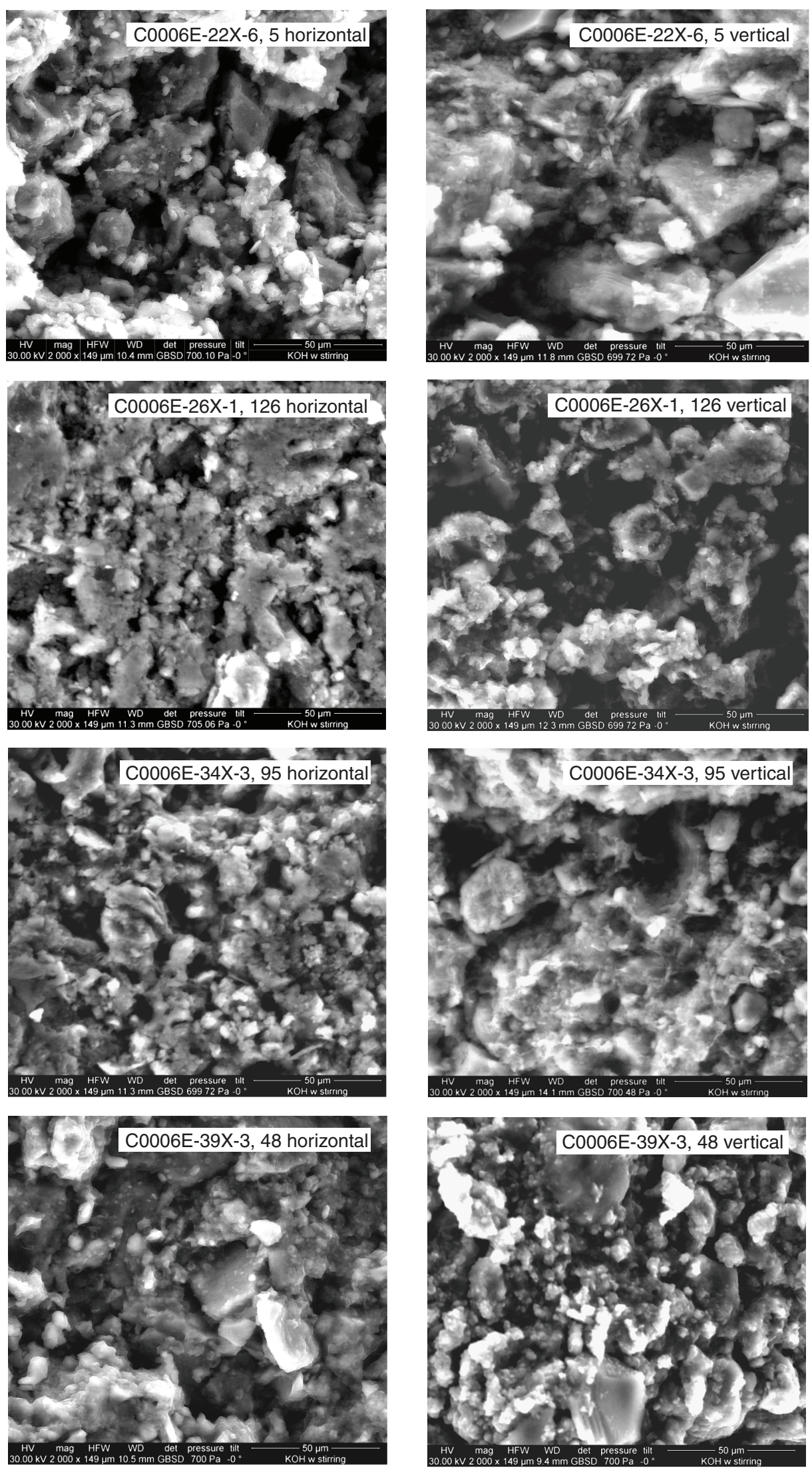
M.K. Ekinci et al.

Figure F9 (continued).
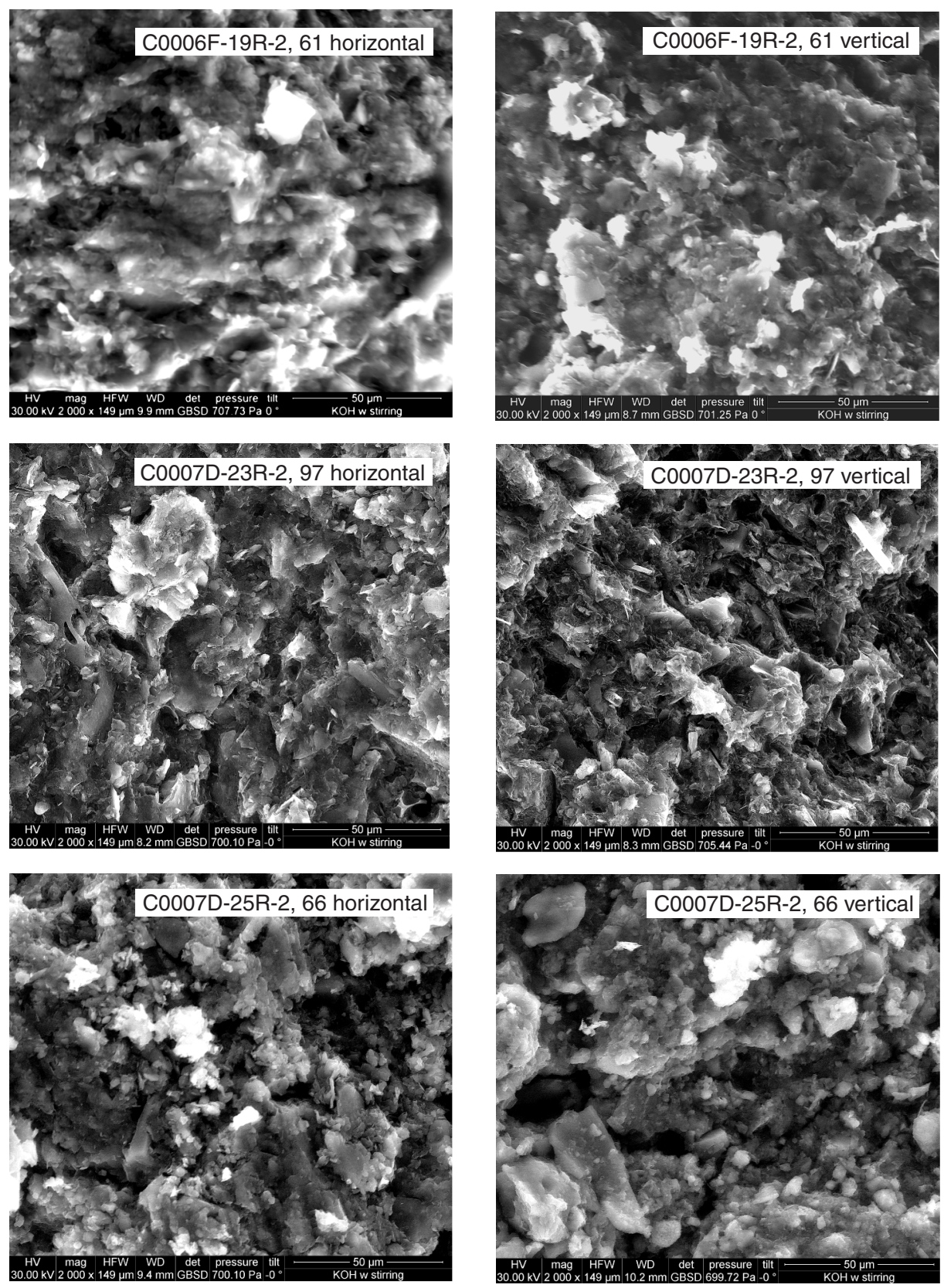
Figure F10. Rose diagrams showing orientation of grains (apparent long axis) measured on environmental scanning electron microscope (ESEM) images from sections cut parallel and perpendicular to the core axis. See Figure F9 for the corresponding ESEM images. Also shown are values of standard deviation (d) for grain orientation and the microfabric orientation index (i). (Continued on next page.)
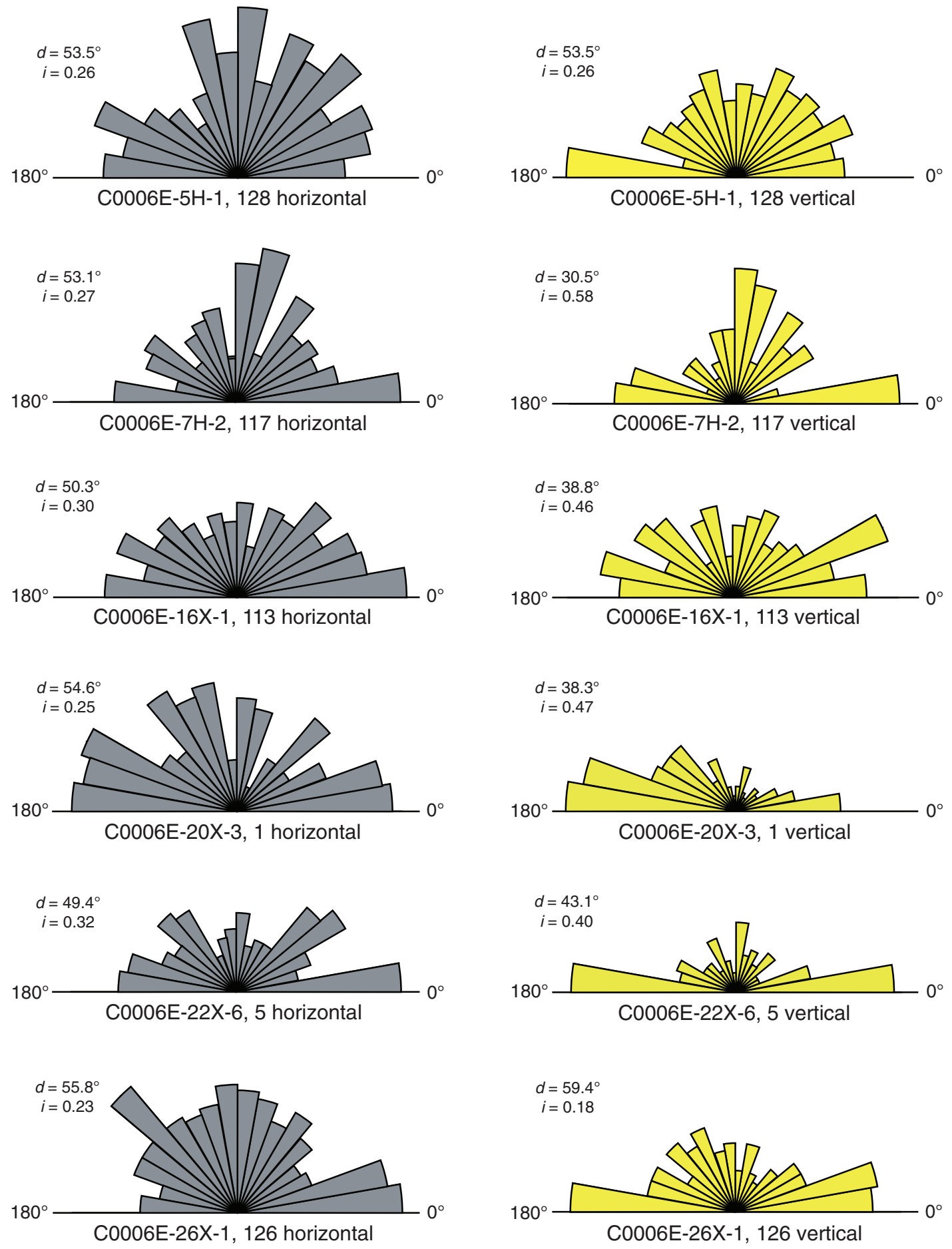


\section{Figure F10 (continued).}
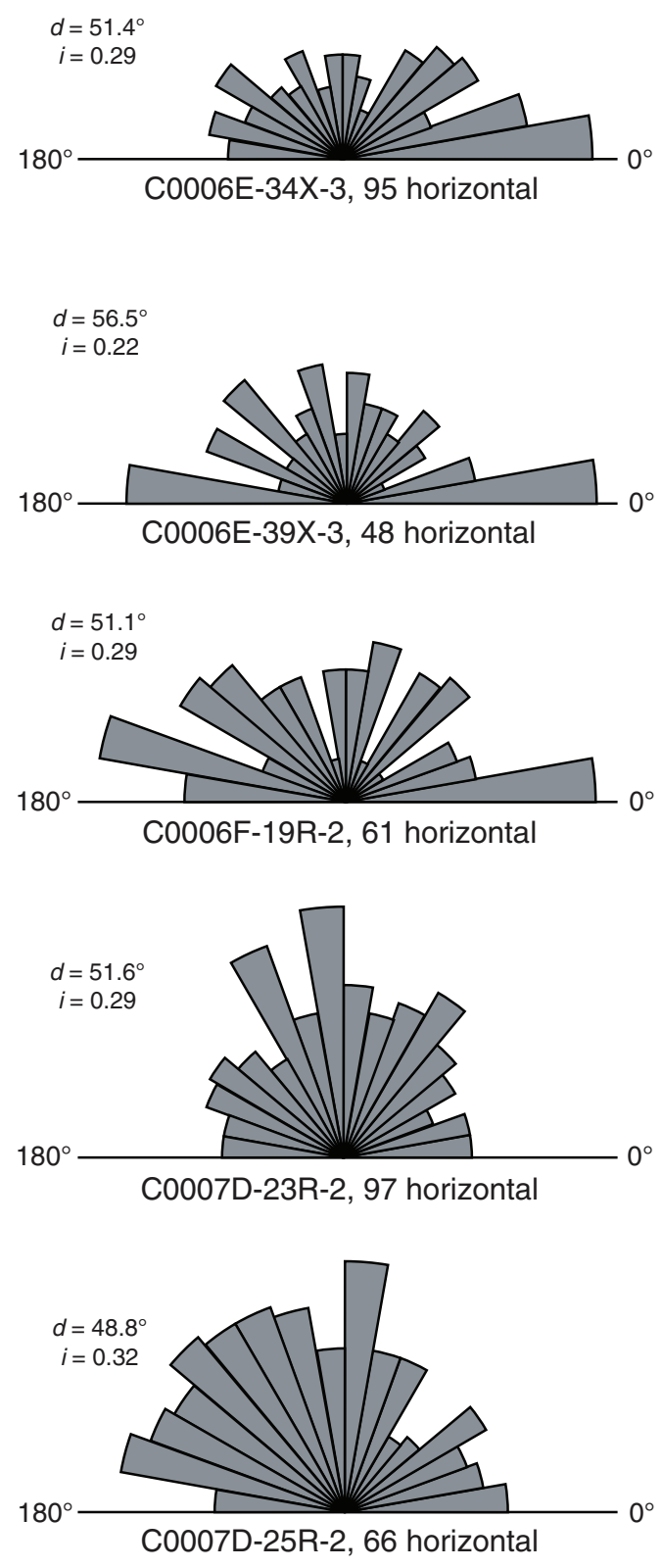
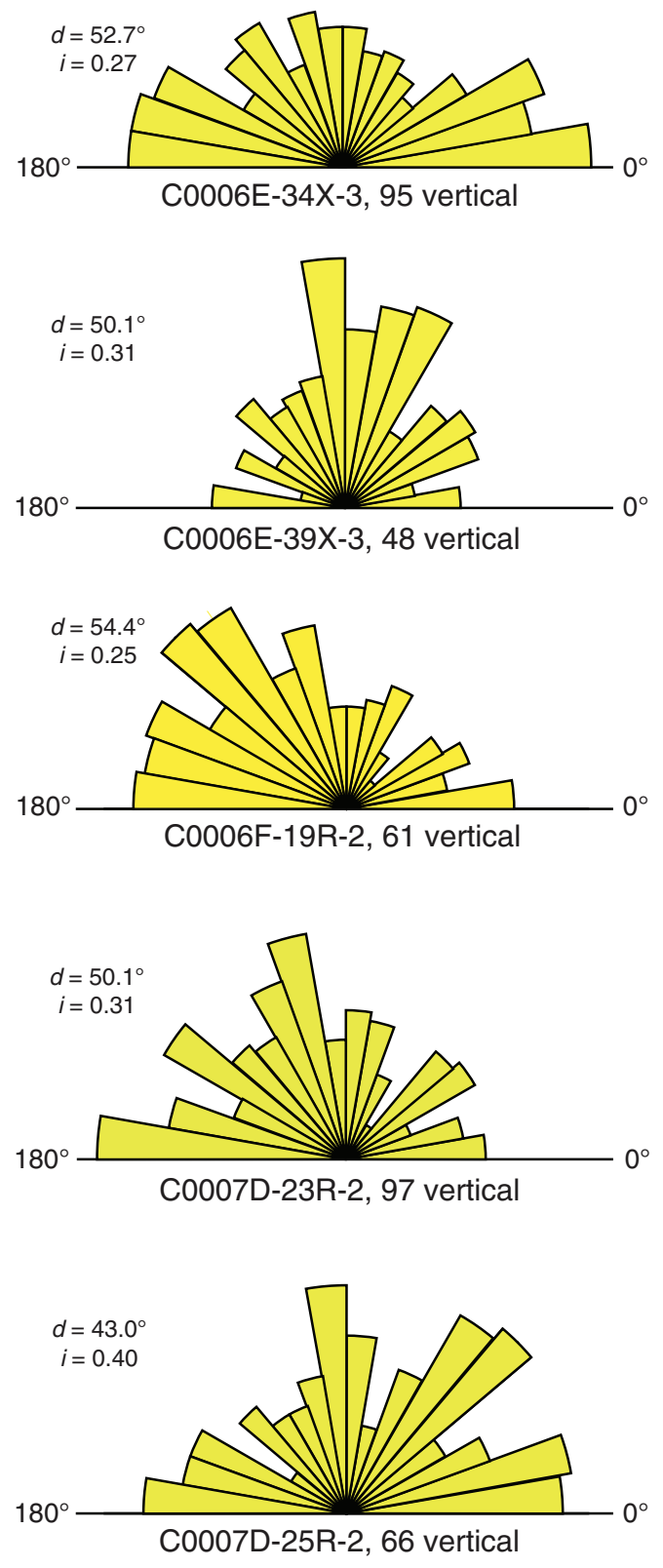
Figure F11. Cumulative frequency curves for grain orientations imaged on horizontal sections (perpendicular to core axis) and vertical sections (parallel to core axis) by environmental scanning electron microscope, Sites C0006 and C0007. Angles of orientation for the grains' apparent long axes were grouped into bins of $10^{\circ}$.
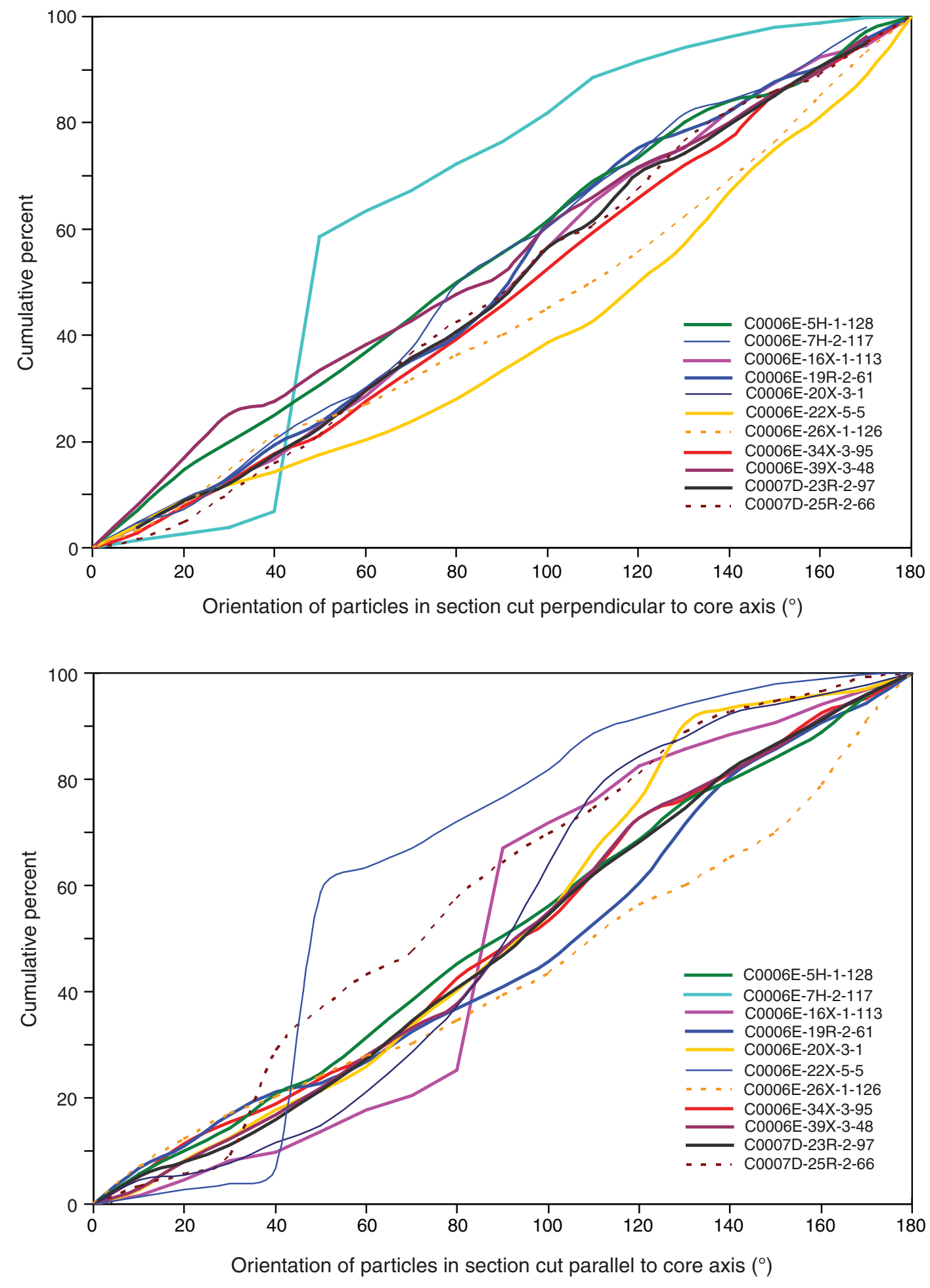
Figure F12. Plots of comparison of anisotropy of permeability (horizontal flow/vertical flow) to (A) the microfabric orientation index (horizontal section) and (B) orientation index ratio (horizontal section/vertical section), Sites C0006 and C0007.
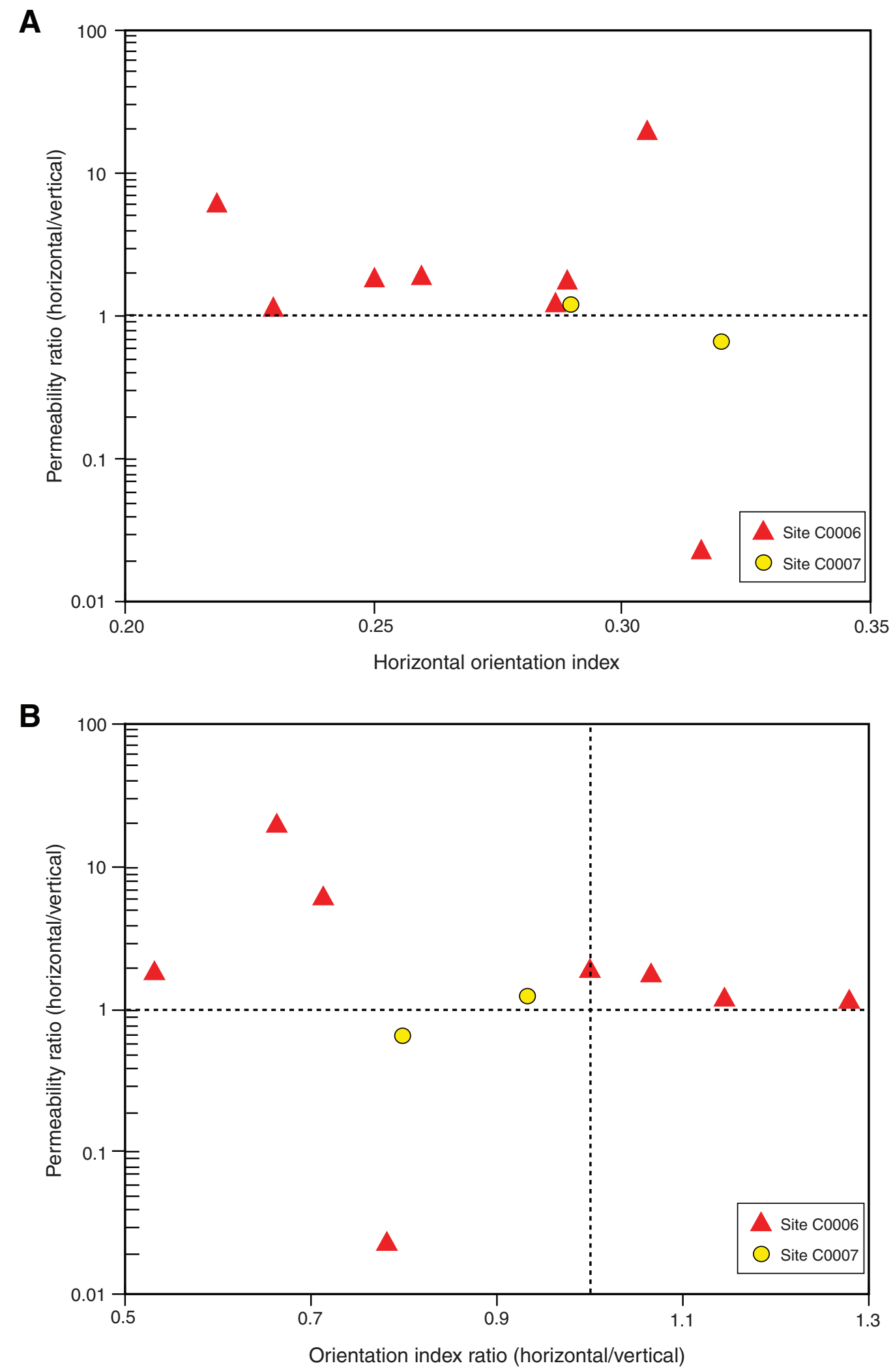


\section{M.K. Ekinci et al.}

Table T1. Summary of specimen properties before and after permeability tests, Sites C0006 and C0007.

\begin{tabular}{|c|c|c|c|c|c|c|c|c|c|c|c|}
\hline \multirow[b]{2}{*}{$\begin{array}{l}\text { Core, section, } \\
\text { interval }(\mathrm{cm})\end{array}$} & \multirow[b]{2}{*}{$\begin{array}{l}\text { Sample } \\
\text { orientation }\end{array}$} & \multirow[b]{2}{*}{$\begin{array}{l}\text { Depth } \\
\text { CSF (m) }\end{array}$} & \multicolumn{2}{|c|}{ Sample average $(\mathrm{cm})$} & \multirow[b]{2}{*}{$\begin{array}{c}\text { Skempton's } \\
B \text {-value }\end{array}$} & \multicolumn{2}{|c|}{ Shipboard data } & \multicolumn{2}{|c|}{ Before test (\%) } & \multicolumn{2}{|c|}{ After test (\%) } \\
\hline & & & $\begin{array}{c}\text { Sample a } \\
\text { Height }\end{array}$ & $\frac{\text { rage }(\mathrm{cm})}{\text { Diameter }}$ & & $\begin{array}{l}\text { Grain density } \\
\left(\mathrm{g} / \mathrm{cm}^{3}\right)\end{array}$ & $\begin{array}{l}\text { Porosity } \\
\text { (\%) }\end{array}$ & $\begin{array}{l}\text { Water } \\
\text { content }\end{array}$ & Porosity & $\begin{array}{l}\text { Water } \\
\text { content }\end{array}$ & Porosity \\
\hline \multicolumn{12}{|l|}{ 316-C0006E- } \\
\hline $5 \mathrm{H}-1,128$ & Horizontal & 34.49 & 5.06 & 4.21 & 1.00 & 2.65 & 47.9 & 28.1 & 42.6 & 28.0 & 42.6 \\
\hline $5 \mathrm{H}-1,128$ & Vertical & & 4.91 & 6.95 & 0.95 & & & 28.0 & 42.6 & 28.0 & 42.6 \\
\hline 7H-2, 117 & Horizontal & 41.20 & - & - & - & 2.46 & 53.5 & - & - & - & - \\
\hline $7 \mathrm{H}-2,117$ & Vertical & & 5.10 & 4.10 & 1.02 & & & 30.9 & 43.2 & 63.6 & 61.0 \\
\hline $16 \mathrm{X}-1,113$ & Horizontal & 89.95 & 4.32 & 3.91 & 0.95 & 2.72 & 45.2 & 24.4 & 39.9 & 25.5 & 40.9 \\
\hline $16 \mathrm{X}-1,113$ & Vertical & & 5.27 & 6.36 & 0.94 & & & 23.9 & 39.4 & 22.0 & 37.4 \\
\hline $20 X-3,1$ & Horizontal & 128.20 & 5.24 & 3.69 & 0.97 & 2.73 & 45.4 & 34.8 & 48.7 & 30.4 & 45.4 \\
\hline $20 X-3,1$ & Vertical & & 5.68 & 4.22 & 0.92 & & & 37.2 & 50.4 & 29.3 & 44.4 \\
\hline $22 X-6,5$ & Horizontal & 150.19 & 3.54 & 3.78 & 0.97 & 2.71 & 39.9 & 28.6 & 43.7 & 24.2 & 39.6 \\
\hline $22 X-6,5$ & Vertical & & 5.56 & 4.01 & 0.94 & & & 28.2 & 43.4 & 23.7 & 39.1 \\
\hline $26 \mathrm{X}-1,126$ & Horizontal & 183.69 & 4.45 & 3.51 & 0.95 & 2.59 & 38.2 & 31.8 & 45.2 & 31.2 & 44.7 \\
\hline $26 \mathrm{X}-1,126$ & Vertical & & 6.08 & 4.23 & 0.96 & & & 31.1 & 44.6 & 27.0 & 41.2 \\
\hline $34 X-3,95$ & Horizontal & 262.09 & 4.17 & 4.21 & 0.95 & 2.64 & 39.5 & 22.9 & 37.6 & 22.6 & 37.3 \\
\hline $34 X-3,95$ & Vertical & & 7.96 & 6.33 & 0.99 & & & 28.8 & 43.2 & 24.9 & 39.7 \\
\hline $39 X-3,48$ & Horizontal & 300.00 & 4.89 & 3.88 & 0.95 & 2.68 & 42.9 & 31.0 & 45.4 & 27.0 & 42.0 \\
\hline $39 X-3,48$ & Vertical & & 4.81 & 4.02 & 0.97 & & & 31.8 & 46.0 & 27.3 & 42.3 \\
\hline \multicolumn{12}{|l|}{ 316-C0006F- } \\
\hline 19R-2, 61 & Horizontal & 563.50 & 3.93 & 4.25 & 0.99 & 2.75 & 39.3 & 27.7 & 43.3 & 25.3 & 41.0 \\
\hline 19R-2, 61 & Vertical & & 4.22 & 4.12 & 0.95 & & & 23.2 & 39.0 & 24.7 & 40.4 \\
\hline \multicolumn{12}{|l|}{ 316-C0007D- } \\
\hline $23 \mathrm{R}-2,97$ & Horizontal & 382.00 & 3.64 & 3.79 & 0.95 & 2.68 & 48.8 & 38.6 & 50.8 & 40.8 & 52.2 \\
\hline $23 \mathrm{R}-2,97$ & Vertical & & 6.71 & 5.73 & 1.01 & & & 29.5 & 44.1 & 39.2 & 51.3 \\
\hline $25 \mathrm{R}-2,66$ & Horizontal & 400.53 & 4.19 & 4.14 & 0.95 & 2.73 & 48.6 & 35.3 & 49.1 & 38.0 & 50.9 \\
\hline $25 \mathrm{R}-2,66$ & Vertical & & 8.56 & 5.72 & 1.01 & & & 35.3 & 49.1 & 38.0 & 50.9 \\
\hline
\end{tabular}

$-=$ no data. 


\section{M.K. Ekinci et al.}

Table T2. Average values of permeability and hydraulic conductivity, Sites C0006 and C0007.

\begin{tabular}{|c|c|c|c|c|c|c|c|}
\hline \multirow{2}{*}{$\begin{array}{l}\text { Core, section, } \\
\text { interval }(\mathrm{cm})\end{array}$} & \multirow{2}{*}{$\begin{array}{l}\text { Depth } \\
\text { CSF (m) }\end{array}$} & \multirow{2}{*}{$\begin{array}{l}\text { Bedding } \\
\text { dip } \\
\left(^{\circ}\right)\end{array}$} & \multicolumn{2}{|c|}{$\begin{array}{l}\text { Hydraulic conductivity } \\
(\mathrm{cm} / \mathrm{s})\end{array}$} & \multicolumn{2}{|c|}{$\begin{array}{l}\text { Intrinsic permeability } \\
\left(\mathrm{m}^{2}\right)\end{array}$} & \multirow{2}{*}{$\begin{array}{c}\text { Permeability } \\
\text { ratio } \\
(\mathrm{H} / \mathrm{V})\end{array}$} \\
\hline & & & Horizontal & Vertical & Horizontal & Vertical & \\
\hline \multicolumn{8}{|l|}{ 316-C0006E- } \\
\hline $5 \mathrm{H}-1,128$ & 34.49 & 43 & $8.25 \mathrm{E}-07$ & $4.33 \mathrm{E}-07$ & $8.42 \mathrm{E}-16$ & $4.42 \mathrm{E}-16$ & 1.91 \\
\hline $7 \mathrm{H}-2,117$ & 41.20 & 46 & - & $7.79 \mathrm{E}-08$ & - & $7.95 \mathrm{E}-17$ & - \\
\hline $16 \mathrm{X}-1,113$ & 89.95 & 31 & 2.07E-06 & $1.04 \mathrm{E}-07$ & $2.11 \mathrm{E}-15$ & $1.06 \mathrm{E}-16$ & 19.90 \\
\hline $20 X-3,1$ & 128.20 & 38 & $3.20 \mathrm{E}-09$ & $1.71 \mathrm{E}-09$ & $3.27 \mathrm{E}-18$ & 1.74E-18 & 1.87 \\
\hline $22 X-6,5$ & 150.19 & 44 & $3.72 \mathrm{E}-08$ & $1.60 \mathrm{E}-06$ & $3.80 \mathrm{E}-17$ & $1.63 \mathrm{E}-15$ & 0.02 \\
\hline $26 \mathrm{X}-1,126$ & 183.69 & 9 & $4.29 \mathrm{E}-09$ & $3.64 \mathrm{E}-09$ & $4.38 \mathrm{E}-18$ & $3.71 \mathrm{E}-18$ & 1.18 \\
\hline $34 X-3,95$ & 262.09 & 14 & $2.20 \mathrm{E}-09$ & $1.24 \mathrm{E}-09$ & $2.24 \mathrm{E}-18$ & 1.27E-18 & 1.77 \\
\hline $39 X-3,48$ & 300.00 & 5 & $1.46 \mathrm{E}-07$ & $2.34 \mathrm{E}-08$ & $1.49 \mathrm{E}-16$ & $2.39 \mathrm{E}-17$ & 6.24 \\
\hline \multicolumn{8}{|l|}{ 316-C0006F- } \\
\hline 19R-2, 61 & 563.50 & - & $3.25 \mathrm{E}-10$ & $2.63 \mathrm{E}-10$ & $3.32 \mathrm{E}-19$ & $2.68 \mathrm{E}-19$ & 1.24 \\
\hline \multicolumn{8}{|l|}{ 316-C0007D- } \\
\hline $23 \mathrm{R}-2,97$ & 382.00 & 3 & $1.15 \mathrm{E}-09$ & $9.54 \mathrm{E}-10$ & 1.17E-18 & $9.73 \mathrm{E}-19$ & 1.21 \\
\hline $25 R-2,66$ & 400.53 & 4 & $8.09 \mathrm{E}-10$ & $1.24 \mathrm{E}-09$ & $8.26 \mathrm{E}-19$ & 1.27E-18 & 0.65 \\
\hline
\end{tabular}

See Table T4 for results of individual test runs. $\mathrm{H}=$ horizontal, $\mathrm{V}=$ vertical. $-=$ no data. 
Table T3. Results of individual permeability tests, Sites C0006 and C0007. (Continued on next page.)

\begin{tabular}{|c|c|c|c|c|c|c|c|}
\hline $\begin{array}{l}\text { Core, section, } \\
\text { interval }(\mathrm{cm})\end{array}$ & Test run & $\begin{array}{l}\text { Volumetric } \\
\text { flow rate } \\
\left(\mathrm{cm}^{3} / \mathrm{min}\right)\end{array}$ & $\begin{array}{l}\text { Discharge } \\
\text { velocity } \\
(\mathrm{cm} / \mathrm{s})\end{array}$ & $\begin{array}{c}\text { Head } \\
\text { difference } \\
(\mathrm{cm})\end{array}$ & $\begin{array}{c}\text { Hydraulic } \\
\text { gradient }\end{array}$ & $\begin{array}{l}\text { Hydraulic } \\
\text { conductivity } \\
(\mathrm{cm} / \mathrm{s})\end{array}$ & $\begin{array}{c}\text { Intrinsic } \\
\text { permeability } \\
\left(\mathrm{m}^{2}\right)\end{array}$ \\
\hline \multicolumn{8}{|l|}{ 316-C0006E- } \\
\hline \multirow[t]{5}{*}{$5 \mathrm{H}-1,128$ vertical } & 1 & 0.007 & $3.52 \mathrm{E}-06$ & 39 & 7.94 & $4.43 \mathrm{E}-07$ & $4.52 \mathrm{E}-16$ \\
\hline & 2 & 0.003 & $1.51 \mathrm{E}-06$ & 19 & 3.87 & $3.89 \mathrm{E}-07$ & $3.97 \mathrm{E}-16$ \\
\hline & 3 & -0.003 & $-3.52 \mathrm{E}-06$ & -37 & -7.54 & 4.67E-07 & 4.77E-16 \\
\hline & 4 & -0.007 & $-1.51 \mathrm{E}-06$ & -17 & -3.46 & $4.35 \mathrm{E}-07$ & $4.44 \mathrm{E}-16$ \\
\hline & & & & & Average: & $4.34 \mathrm{E}-07$ & $4.42 \mathrm{E}-16$ \\
\hline \multirow[t]{5}{*}{$5 \mathrm{H}-1,128$ horizontal } & 1 & 0.007 & $8.39 \mathrm{E}-06$ & 52 & 10.28 & $8.16 \mathrm{E}-07$ & $8.33 \mathrm{E}-16$ \\
\hline & 2 & 0.003 & $3.59 \mathrm{E}-06$ & 22 & 4.35 & $8.26 \mathrm{E}-07$ & $8.43 \mathrm{E}-16$ \\
\hline & 3 & -0.007 & $-8.39 \mathrm{E}-06$ & -51 & -10.08 & $8.32 \mathrm{E}-07$ & $8.49 \mathrm{E}-16$ \\
\hline & 4 & -0.003 & $-3.59 \mathrm{E}-06$ & -22 & -4.35 & $8.26 \mathrm{E}-07$ & $8.43 \mathrm{E}-16$ \\
\hline & & & & & Average: & $8.25 \mathrm{E}-07$ & $8.42 \mathrm{E}-16$ \\
\hline \multirow[t]{5}{*}{$7 \mathrm{H}-2,117$ vertical } & 1 & 0.003 & 3.79E-06 & 268 & 52.55 & $7.21 \mathrm{E}-08$ & 7.36E-17 \\
\hline & 2 & 0.001 & $1.26 \mathrm{E}-06$ & 90 & 17.65 & 7.15E-08 & $7.30 \mathrm{E}-17$ \\
\hline & 3 & -0.003 & $-3.79 \mathrm{E}-06$ & -258 & -50.59 & 7.49E-08 & $7.64 \mathrm{E}-17$ \\
\hline & 4 & -0.001 & $-1.26 \mathrm{E}-06$ & -69 & -13.53 & $9.33 \mathrm{E}-08$ & $9.52 \mathrm{E}-17$ \\
\hline & & & & & Average: & $7.80 \mathrm{E}-08$ & $7.95 \mathrm{E}-17$ \\
\hline \multirow[t]{5}{*}{$16 \mathrm{X}-1,113$ horizontal } & 1 & 0.005 & $6.94 \mathrm{E}-06$ & 12 & 2.78 & $2.50 \mathrm{E}-06$ & $2.55 \mathrm{E}-15$ \\
\hline & 2 & 0.008 & $1.11 \mathrm{E}-05$ & 24 & 5.56 & 2.00E-06 & 2.04E-15 \\
\hline & 3 & -0.008 & $-1.11 \mathrm{E}-05$ & -25 & -5.79 & 1.92E-06 & $1.96 \mathrm{E}-15$ \\
\hline & 4 & -0.005 & $-6.93 \mathrm{E}-06$ & -16 & -3.70 & 1.87E-06 & $1.91 \mathrm{E}-15$ \\
\hline & & & & & Average: & 2.07E-06 & $2.11 \mathrm{E}-15$ \\
\hline \multirow[t]{5}{*}{$16 \mathrm{X}-1,113$ vertical } & 1 & 0.005 & $2.61 \mathrm{E}-06$ & 130 & 24.67 & $1.06 \mathrm{E}-07$ & 1.08E-16 \\
\hline & 2 & 0.003 & $1.58 \mathrm{E}-06$ & 80 & 15.18 & $1.04 \mathrm{E}-07$ & $1.06 \mathrm{E}-16$ \\
\hline & 3 & -0.005 & $-2.63 \mathrm{E}-06$ & -132 & -25.05 & $1.05 \mathrm{E}-07$ & 1.07E-16 \\
\hline & 4 & -0.003 & $-1.57 \mathrm{E}-06$ & -81 & -15.37 & $1.02 \mathrm{E}-07$ & $1.04 \mathrm{E}-16$ \\
\hline & & & & & Average: & $1.04 \mathrm{E}-07$ & $1.06 \mathrm{E}-16$ \\
\hline \multirow[t]{5}{*}{$20 \mathrm{X}-3,1$ vertical } & 1 & 0.0002 & $3.21 \mathrm{E}-07$ & 858 & 203.32 & $1.58 \mathrm{E}-09$ & $1.61 \mathrm{E}-18$ \\
\hline & 2 & 0.0001 & $1.60 \mathrm{E}-07$ & 423 & 100.24 & 1.60E-09 & $1.63 \mathrm{E}-18$ \\
\hline & 3 & -0.0002 & $-3.20 \mathrm{E}-07$ & -722 & -171.09 & 1.87E-09 & $1.91 \mathrm{E}-18$ \\
\hline & 4 & -0.0001 & $-1.60 \mathrm{E}-07$ & -380 & -90.05 & $1.78 \mathrm{E}-09$ & $1.82 \mathrm{E}-18$ \\
\hline & & & & & Average: & $1.71 \mathrm{E}-09$ & $1.74 \mathrm{E}-18$ \\
\hline \multirow[t]{5}{*}{$20 \mathrm{X}-3,1$ horizontal } & 1 & 0.0001 & $1.56 \mathrm{E}-07$ & 265 & 50.57 & $3.08 \mathrm{E}-09$ & $3.14 \mathrm{E}-18$ \\
\hline & 2 & 0.0002 & $3.12 \mathrm{E}-07$ & 512 & 97.71 & 3.19E-09 & $3.26 \mathrm{E}-18$ \\
\hline & 3 & -0.0001 & $-1.56 \mathrm{E}-07$ & -251 & -47.90 & $3.25 \mathrm{E}-09$ & $3.32 \mathrm{E}-18$ \\
\hline & 4 & -0.0002 & $-3.12 \mathrm{E}-07$ & -498 & -95.04 & $3.28 \mathrm{E}-09$ & $3.35 \mathrm{E}-18$ \\
\hline & & & & & Average: & $3.20 \mathrm{E}-09$ & 3.27E-18 \\
\hline \multirow[t]{5}{*}{$22 X-6,5$ vertical } & 1 & 0.003 & $3.96 \mathrm{E}-06$ & 144 & 25.90 & $1.53 \mathrm{E}-07$ & $1.56 \mathrm{E}-16$ \\
\hline & 2 & 0.007 & $9.23 \mathrm{E}-06$ & 331 & 59.53 & $1.55 \mathrm{E}-07$ & $1.58 \mathrm{E}-16$ \\
\hline & 3 & -0.003 & $-3.96 \mathrm{E}-06$ & -142 & -25.54 & 1.55E-07 & $1.58 \mathrm{E}-16$ \\
\hline & 4 & -0.007 & $-9.26 \mathrm{E}-06$ & -330 & -59.35 & $1.56 \mathrm{E}-07$ & $1.59 \mathrm{E}-16$ \\
\hline & & & & & Average: & $1.55 \mathrm{E}-07$ & $1.58 \mathrm{E}-16$ \\
\hline \multirow[t]{5}{*}{$22 X-6,5$ horizontal } & 1 & 0.003 & $4.45 \mathrm{E}-06$ & 425 & 120.06 & $3.71 \mathrm{E}-08$ & $3.79 \mathrm{E}-17$ \\
\hline & 2 & 0.001 & $1.48 \mathrm{E}-06$ & 139 & 39.27 & $3.78 \mathrm{E}-08$ & $3.86 \mathrm{E}-17$ \\
\hline & 3 & -0.003 & $-4.46 \mathrm{E}-06$ & -424 & -119.77 & $3.72 \mathrm{E}-08$ & $3.80 \mathrm{E}-17$ \\
\hline & 4 & -0.001 & $-1.49 \mathrm{E}-06$ & -143 & -40.40 & $3.68 \mathrm{E}-08$ & $3.76 \mathrm{E}-17$ \\
\hline & & & & & Average: & $3.72 \mathrm{E}-08$ & $3.80 \mathrm{E}-17$ \\
\hline \multirow[t]{5}{*}{$26 \mathrm{X}-1,126$ vertical } & 1 & 0.0003 & $3.56 \mathrm{E}-07$ & 596 & 98.03 & 3.63E-09 & $3.70 \mathrm{E}-18$ \\
\hline & 2 & 0.0001 & $1.19 \mathrm{E}-07$ & 194 & 31.91 & 3.72E-09 & $3.80 \mathrm{E}-18$ \\
\hline & 3 & -0.0003 & $-3.56 \mathrm{E}-07$ & -603 & -99.18 & $3.59 \mathrm{E}-09$ & $3.66 \mathrm{E}-18$ \\
\hline & 4 & -0.0001 & $-1.18 \mathrm{E}-07$ & -199 & -32.73 & $3.62 \mathrm{E}-09$ & $3.69 \mathrm{E}-18$ \\
\hline & & & & & Average: & $3.64 \mathrm{E}-09$ & 3.71E-18 \\
\hline \multirow[t]{5}{*}{$26 \mathrm{X}-1,126$ horizontal } & 1 & 0.0003 & $5.17 \mathrm{E}-07$ & 540 & 121.35 & $4.26 \mathrm{E}-09$ & $4.35 \mathrm{E}-18$ \\
\hline & 2 & 0.0001 & $1.72 \mathrm{E}-07$ & 180 & 40.45 & $4.26 \mathrm{E}-09$ & $4.35 \mathrm{E}-18$ \\
\hline & 3 & -0.0003 & $-5.17 \mathrm{E}-07$ & -529 & -118.88 & 4.35E-09 & 4.44E-18 \\
\hline & 4 & -0.0001 & $-1.72 \mathrm{E}-07$ & -178 & -40.00 & 4.31E-09 & $4.40 \mathrm{E}-18$ \\
\hline & & & & & Average: & 4.29E-09 & $4.38 \mathrm{E}-18$ \\
\hline \multirow[t]{5}{*}{$34 X-3,95$ vertical } & 1 & 0.0001 & $5.31 \mathrm{E}-08$ & 304 & 38.19 & $1.39 \mathrm{E}-09$ & $1.42 \mathrm{E}-18$ \\
\hline & 2 & 0.0002 & $1.06 \mathrm{E}-07$ & 648 & 81.41 & $1.30 \mathrm{E}-09$ & $1.33 \mathrm{E}-18$ \\
\hline & 3 & -0.0001 & $-5.32 \mathrm{E}-08$ & -419 & -52.64 & $1.01 \mathrm{E}-09$ & $1.03 \mathrm{E}-18$ \\
\hline & 4 & -0.0002 & $-1.07 \mathrm{E}-07$ & -679 & -85.30 & $1.25 \mathrm{E}-09$ & $1.28 \mathrm{E}-18$ \\
\hline & & & & & Average: & $1.24 \mathrm{E}-09$ & $1.26 \mathrm{E}-18$ \\
\hline
\end{tabular}


Table T3 (continued).

\begin{tabular}{|c|c|c|c|c|c|c|c|}
\hline $\begin{array}{l}\text { Core, section, } \\
\text { interval }(\mathrm{cm})\end{array}$ & Test run & $\begin{array}{l}\text { Volumetric } \\
\text { flow rate } \\
\left(\mathrm{cm}^{3} / \mathrm{min}\right)\end{array}$ & $\begin{array}{l}\text { Discharge } \\
\text { velocity } \\
(\mathrm{cm} / \mathrm{s})\end{array}$ & $\begin{array}{c}\text { Head } \\
\text { difference } \\
(\mathrm{cm})\end{array}$ & $\begin{array}{l}\text { Hydraulic } \\
\text { gradient }\end{array}$ & $\begin{array}{l}\text { Hydraulic } \\
\text { conductivity } \\
(\mathrm{cm} / \mathrm{s})\end{array}$ & $\begin{array}{c}\text { Intrinsic } \\
\text { permeability } \\
\left(\mathrm{m}^{2}\right)\end{array}$ \\
\hline \multirow[t]{5}{*}{$34 X-3,95$ horizontal } & 1 & 0.0002 & $2.39 \mathrm{E}-07$ & 455 & 109.11 & 2.19E-09 & $2.23 \mathrm{E}-18$ \\
\hline & 2 & 0.0001 & $1.20 \mathrm{E}-07$ & 221 & 53.00 & $2.26 \mathrm{E}-09$ & $2.31 \mathrm{E}-18$ \\
\hline & 3 & -0.0002 & $-2.39 \mathrm{E}-07$ & -453 & -108.63 & $2.20 \mathrm{E}-09$ & $2.24 \mathrm{E}-18$ \\
\hline & 4 & -0.0001 & $-1.20 \mathrm{E}-07$ & -231 & -55.40 & $2.16 \mathrm{E}-09$ & $2.20 \mathrm{E}-18$ \\
\hline & & & & & Average: & $2.20 \mathrm{E}-09$ & $2.25 \mathrm{E}-18$ \\
\hline \multirow[t]{5}{*}{$39 X-3,48$ vertical } & 1 & 0.0005 & $6.56 \mathrm{E}-07$ & 136 & 28.27 & $2.32 \mathrm{E}-08$ & $2.37 \mathrm{E}-17$ \\
\hline & 2 & 0.0003 & $3.94 \mathrm{E}-07$ & 81 & 16.84 & $2.34 \mathrm{E}-08$ & $2.39 \mathrm{E}-17$ \\
\hline & 3 & -0.0005 & $-6.56 \mathrm{E}-07$ & -132 & -27.44 & $2.39 \mathrm{E}-08$ & $2.44 \mathrm{E}-17$ \\
\hline & 4 & -0.0003 & $-3.94 \mathrm{E}-07$ & -82 & -17.05 & $2.31 \mathrm{E}-08$ & $2.36 \mathrm{E}-17$ \\
\hline & & & & & Average: & $2.34 \mathrm{E}-08$ & $2.39 \mathrm{E}-17$ \\
\hline \multirow[t]{5}{*}{$39 \mathrm{X}-3,48$ horizontal } & 1 & 0.0007 & $9.87 \mathrm{E}-07$ & 34 & 6.95 & $1.42 \mathrm{E}-07$ & $1.45 \mathrm{E}-16$ \\
\hline & 2 & 0.0003 & $4.24 \mathrm{E}-06$ & 140 & 28.63 & $1.48 \mathrm{E}-07$ & $1.51 \mathrm{E}-16$ \\
\hline & 3 & -0.0007 & $-9.85 \mathrm{E}-07$ & -33 & -6.75 & $1.46 \mathrm{E}-07$ & $1.49 \mathrm{E}-16$ \\
\hline & 4 & -0.0003 & $-4.24 \mathrm{E}-06$ & -140 & -28.63 & $1.48 \mathrm{E}-07$ & $1.51 \mathrm{E}-16$ \\
\hline & & & & & Average: & $1.46 \mathrm{E}-07$ & $1.49 \mathrm{E}-16$ \\
\hline \multicolumn{8}{|l|}{ 316-C0006F- } \\
\hline \multirow[t]{5}{*}{ 19R-2, 61 vertical } & 1 & 0.00004 & $5.01 \mathrm{E}-08$ & 755 & 178.91 & $2.80 \mathrm{E}-10$ & $2.86 \mathrm{E}-19$ \\
\hline & 2 & 0.00002 & $2.50 \mathrm{E}-08$ & 383 & 90.76 & $2.75 \mathrm{E}-10$ & $2.81 \mathrm{E}-19$ \\
\hline & 3 & -0.00004 & $-5.00 \mathrm{E}-08$ & -723 & -171.33 & $2.92 \mathrm{E}-10$ & $2.98 \mathrm{E}-19$ \\
\hline & 4 & -0.00002 & $-2.50 \mathrm{E}-08$ & -510 & -120.85 & $2.07 \mathrm{E}-10$ & $2.11 \mathrm{E}-19$ \\
\hline & & & & & Average: & $2.64 \mathrm{E}-10$ & 2.69E-19 \\
\hline \multirow[t]{5}{*}{ 19R-2, 61 horizontal } & 1 & 0.00002 & $2.35 \mathrm{E}-08$ & 255 & 64.89 & $3.62 \mathrm{E}-10$ & $3.69 \mathrm{E}-19$ \\
\hline & 2 & 0.00001 & $1.17 \mathrm{E}-08$ & 142 & 36.13 & $3.25 \mathrm{E}-10$ & $3.32 \mathrm{E}-19$ \\
\hline & 3 & -0.00002 & $-2.35 \mathrm{E}-08$ & -279 & -70.99 & $3.31 \mathrm{E}-10$ & $3.38 \mathrm{E}-19$ \\
\hline & 4 & -0.00001 & $-1.18 \mathrm{E}-08$ & -165 & -41.98 & $2.80 \mathrm{E}-10$ & $2.86 \mathrm{E}-19$ \\
\hline & & & & & Average: & $3.25 \mathrm{E}-10$ & $3.31 \mathrm{E}-19$ \\
\hline \multicolumn{8}{|l|}{ 316-C0007D- } \\
\hline \multirow[t]{5}{*}{ 23R-2, 97 vertical } & 1 & 0.0001 & $6.46 \mathrm{E}-08$ & 421 & 62.74 & $1.03 \mathrm{E}-09$ & $1.05 \mathrm{E}-18$ \\
\hline & 2 & 0.00007 & $4.53 \mathrm{E}-08$ & 295 & 43.96 & $1.03 \mathrm{E}-09$ & $1.05 \mathrm{E}-18$ \\
\hline & 3 & -0.0001 & $-6.47 \mathrm{E}-08$ & -514 & -76.60 & $8.44 \mathrm{E}-10$ & 8.61E-19 \\
\hline & 4 & -0.00007 & $-4.53 \mathrm{E}-08$ & -333 & -49.63 & $9.12 \mathrm{E}-10$ & $9.31 \mathrm{E}-19$ \\
\hline & & & & & Average: & $9.54 \mathrm{E}-10$ & $9.73 \mathrm{E}-19$ \\
\hline \multirow[t]{5}{*}{ 23R-2, 97 horizontal } & 1 & 0.0001 & $1.47 \mathrm{E}-07$ & 467 & 127.95 & $1.15 \mathrm{E}-09$ & $1.17 \mathrm{E}-18$ \\
\hline & 2 & 0.00007 & $1.03 \mathrm{E}-07$ & 329 & 90.14 & $1.14 \mathrm{E}-09$ & $1.16 \mathrm{E}-18$ \\
\hline & 3 & -0.0001 & $-1.47 \mathrm{E}-07$ & -472 & -129.32 & $1.14 \mathrm{E}-09$ & $1.16 \mathrm{E}-18$ \\
\hline & 4 & -0.00007 & $-1.03 \mathrm{E}-07$ & -327 & -89.59 & $1.15 \mathrm{E}-09$ & 1.17E-18 \\
\hline & & & & & Average: & $1.15 \mathrm{E}-09$ & $1.17 \mathrm{E}-18$ \\
\hline \multirow[t]{5}{*}{$25 \mathrm{R}-2,66$ vertical } & 1 & 0.0001 & $6.51 \mathrm{E}-08$ & 516 & 60.28 & $1.08 \mathrm{E}-09$ & $1.10 \mathrm{E}-18$ \\
\hline & 2 & 0.00007 & $4.55 \mathrm{E}-08$ & 207 & 24.18 & $1.88 \mathrm{E}-09$ & $1.92 \mathrm{E}-18$ \\
\hline & 3 & -0.0001 & $-6.47 E-08$ & -543 & -63.43 & $1.02 \mathrm{E}-09$ & $1.04 \mathrm{E}-18$ \\
\hline & 4 & -0.00007 & $-4.54 \mathrm{E}-08$ & -389 & -45.44 & $9.99 \mathrm{E}-10$ & $1.02 \mathrm{E}-18$ \\
\hline & & & & & Average: & $1.24 \mathrm{E}-09$ & $1.27 \mathrm{E}-18$ \\
\hline \multirow[t]{5}{*}{$25 \mathrm{R}-2,66$ horizontal } & 1 & 0.00007 & $8.69 \mathrm{E}-08$ & 445 & 106.46 & $8.16 \mathrm{E}-10$ & $8.33 \mathrm{E}-19$ \\
\hline & 2 & 0.00009 & $1.12 \mathrm{E}-07$ & 559 & 133.73 & $8.35 \mathrm{E}-10$ & $8.52 \mathrm{E}-19$ \\
\hline & 3 & -0.00007 & $-8.69 \mathrm{E}-08$ & -473 & -113.16 & $7.68 \mathrm{E}-10$ & $7.84 \mathrm{E}-19$ \\
\hline & 4 & -0.00009 & $-1.12 \mathrm{E}-07$ & -572 & -136.84 & $8.16 \mathrm{E}-10$ & $8.33 \mathrm{E}-19$ \\
\hline & & & & & Average: & $8.09 \mathrm{E}-10$ & $8.25 \mathrm{E}-19$ \\
\hline
\end{tabular}




\section{M.K. Ekinci et al.}

Table T4. Fabric orientation statistics calculated from analyses of environmental SEM images, Sites C0006 and C0007.

\begin{tabular}{|c|c|c|c|c|c|c|c|}
\hline \multirow[b]{2}{*}{$\begin{array}{l}\text { Core, section, } \\
\text { interval }(\mathrm{cm})\end{array}$} & \multirow[b]{2}{*}{$\begin{array}{l}\text { Depth } \\
\text { CSF }(m)\end{array}$} & \multirow[b]{2}{*}{$\begin{array}{l}\text { Grains } \\
\text { counted }\end{array}$} & \multicolumn{2}{|c|}{ Horizontal section } & \multirow[b]{2}{*}{$\begin{array}{l}\text { Grains } \\
\text { counted }\end{array}$} & \multicolumn{2}{|c|}{ Vertical section } \\
\hline & & & $\begin{array}{c}\text { SD of } \\
\text { orientation }\left(^{\circ}\right)\end{array}$ & $\begin{array}{l}\text { Index of } \\
\text { orientation }\end{array}$ & & $\begin{array}{c}\text { SD of } \\
\text { orientation }\left(^{\circ}\right)\end{array}$ & $\begin{array}{l}\text { Index of } \\
\text { orientation }\end{array}$ \\
\hline \multicolumn{8}{|l|}{ 316-C0006E- } \\
\hline $5 \mathrm{H}-1,128$ & 34.49 & 252 & 53.5 & 0.26 & 232 & 53.5 & 0.26 \\
\hline 7H-2, 117 & 41.20 & 200 & 53.1 & 0.27 & 341 & 30.5 & 0.58 \\
\hline $16 X-1,113$ & 89.95 & 391 & 50.3 & 0.30 & 258 & 38.8 & 0.46 \\
\hline $20 X-3,1$ & 128.20 & 433 & 54.6 & 0.25 & 217 & 38.3 & 0.47 \\
\hline $22 X-6,5$ & 150.19 & 192 & 49.4 & 0.32 & 500 & 43.1 & 0.40 \\
\hline $26 \mathrm{X}-1,126$ & 183.69 & 393 & 55.8 & 0.23 & 423 & 59.4 & 0.18 \\
\hline $34 X-3,95$ & 262.09 & 293 & 51.4 & 0.29 & 212 & 52.7 & 0.27 \\
\hline $39 X-3,48$ & 300.00 & 640 & 56.5 & 0.22 & 275 & 50.1 & 0.31 \\
\hline \multicolumn{8}{|l|}{ 316-C0006F- } \\
\hline 19R-2, 61 & 563.50 & 361 & 51.1 & 0.29 & 500 & 54.4 & 0.25 \\
\hline \multicolumn{8}{|l|}{ 316-C0007D- } \\
\hline $23 \mathrm{R}-2,97$ & 382.00 & 315 & 51.6 & 0.29 & 290 & 50.1 & 0.31 \\
\hline $25 R-2,66$ & 400.53 & 264 & 48.8 & 0.32 & 450 & 43.0 & 0.40 \\
\hline
\end{tabular}

$\mathrm{SD}=$ standard deviation. 


\section{Appendix}

Hydraulic gradient and discharge velocity

Plots of hydraulic gradient versus discharge velocity for various samples are presented in Figures AF1, AF2, AF3, AF4, AF5, AF6, AF7, AF8, AF9, AF10, and AF11. 
Figure AF1. Hydraulic gradient vs. discharge velocity (Sample 316-C0006E-5H-1, 128 cm).

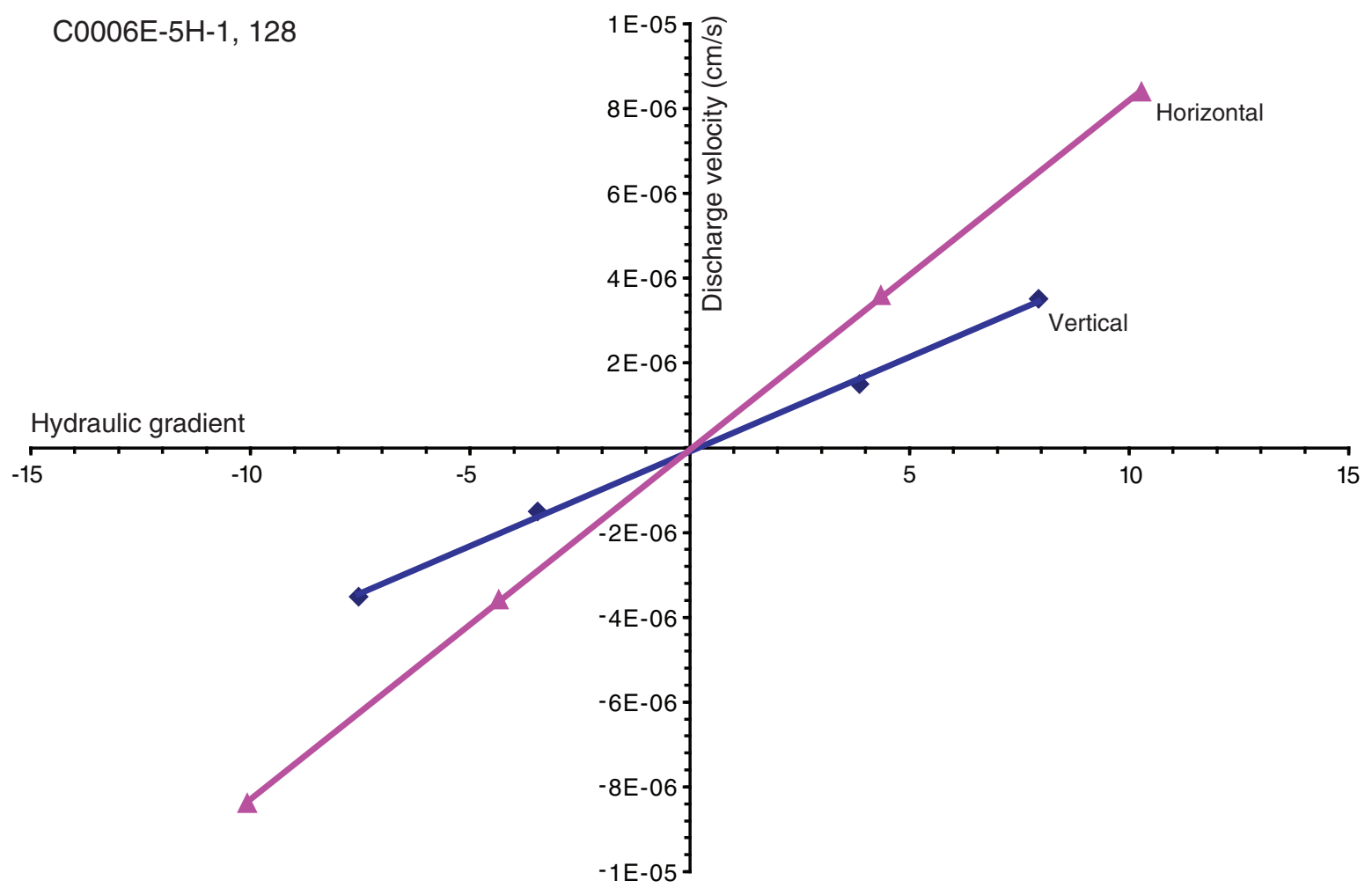


Figure AF2. Hydraulic gradient vs. discharge velocity (Sample 316-C0006E-7H-2, 117 cm).

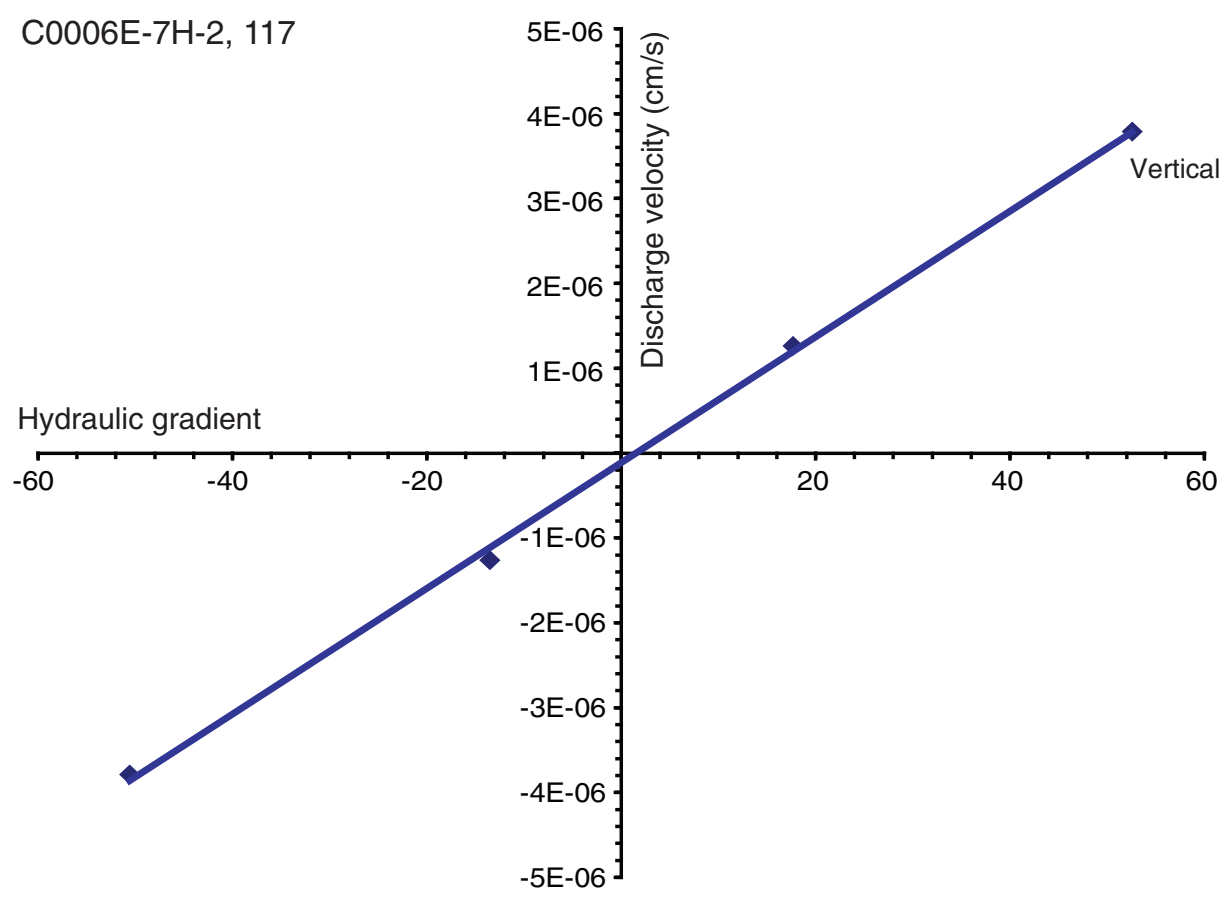


Figure AF3. Hydraulic gradient vs. discharge velocity (Sample 316-C0006E-16X-1, $113 \mathrm{~cm}$ ).

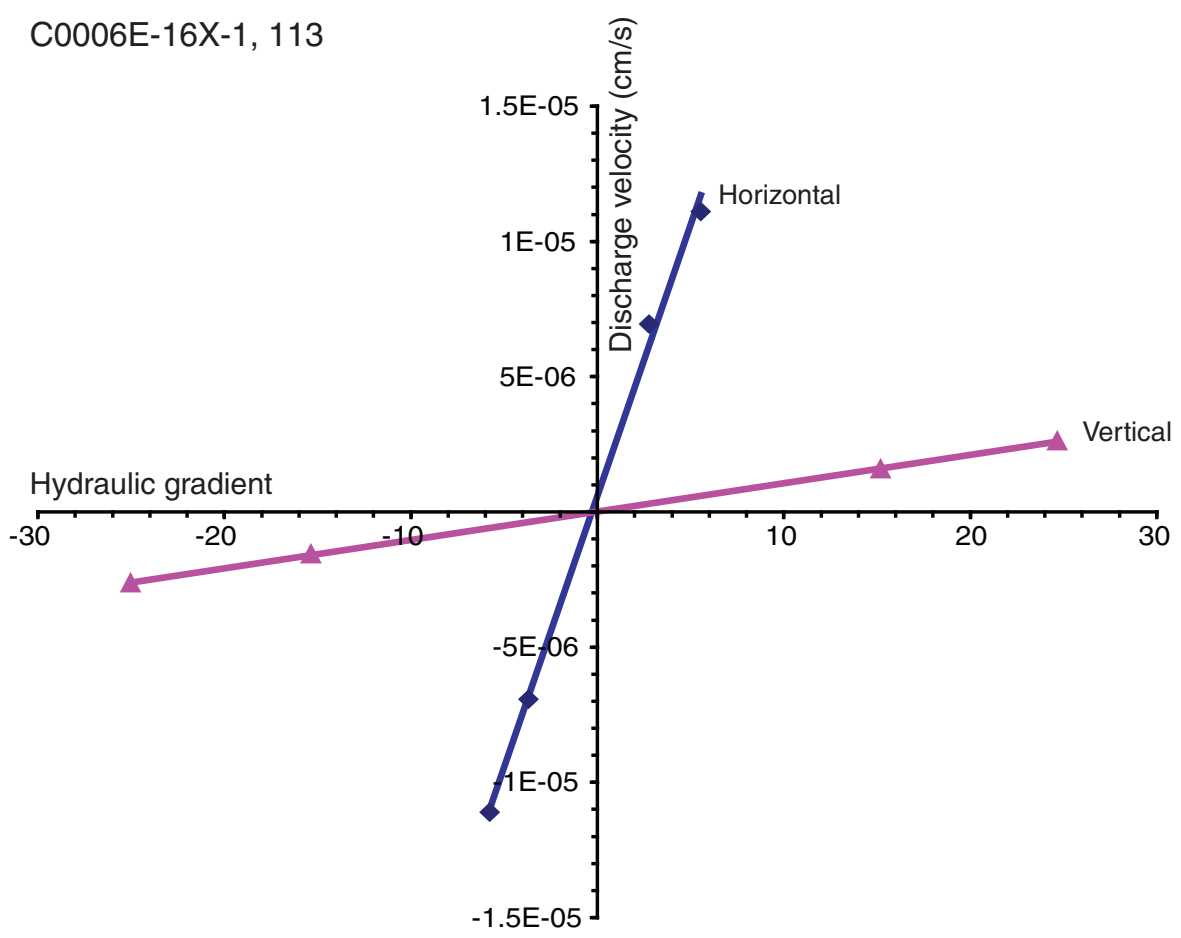


Figure AF4. Hydraulic gradient vs. discharge velocity (Sample 316-C0006E-20X-3, $1 \mathrm{~cm}$ ).

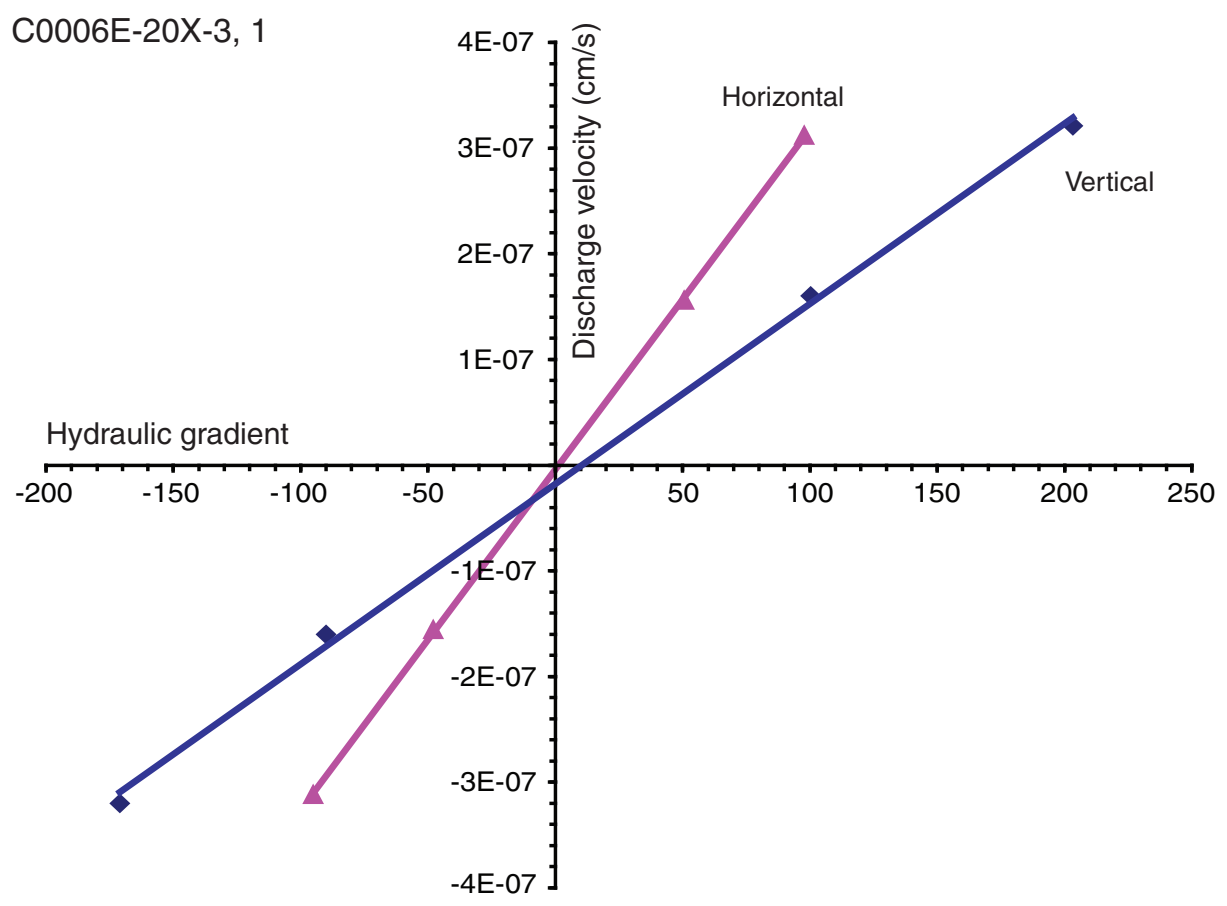


Figure AF5. Hydraulic gradient vs. discharge velocity (Sample 316-C0006E-22X-6, 5 cm).

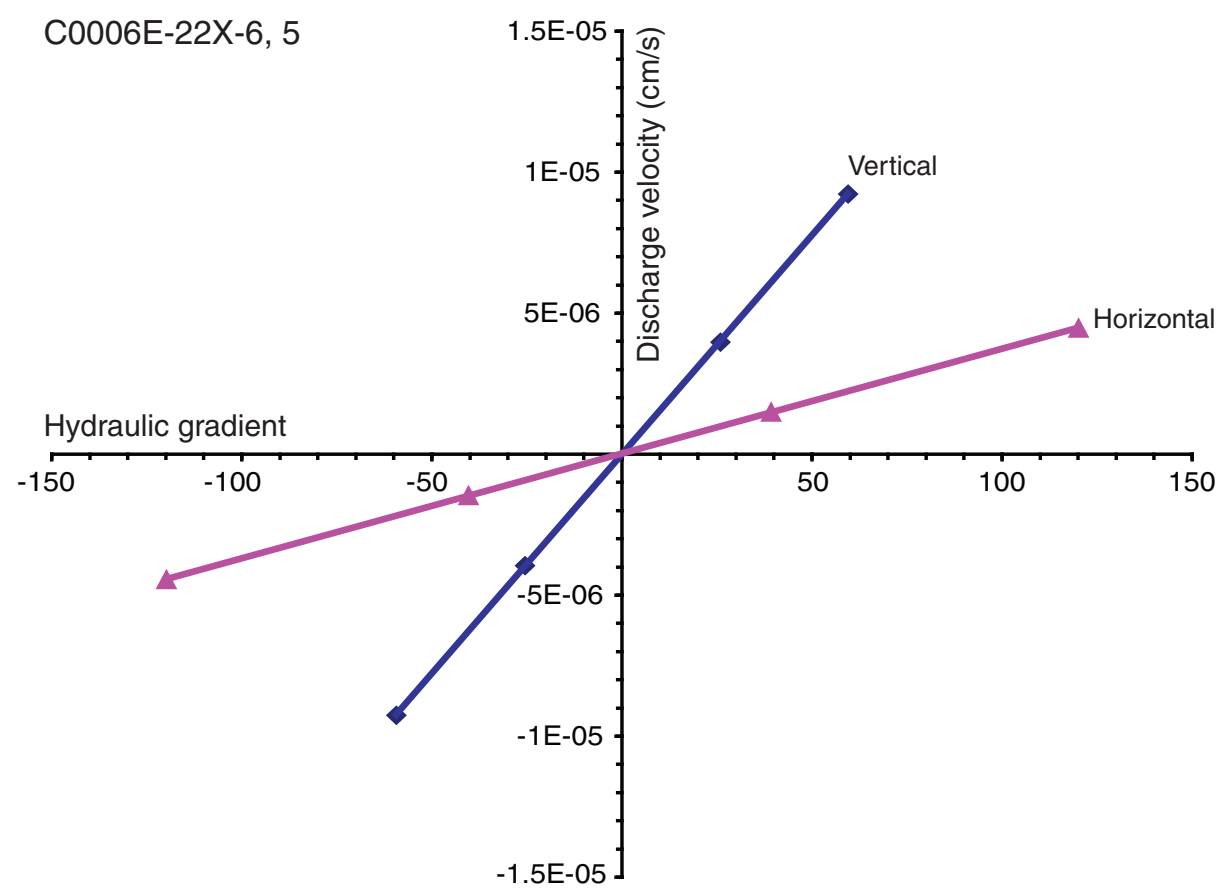


Figure AF6. Hydraulic gradient vs. discharge velocity (Sample 316-C0006E-26X-1, $126 \mathrm{~cm}$ ).

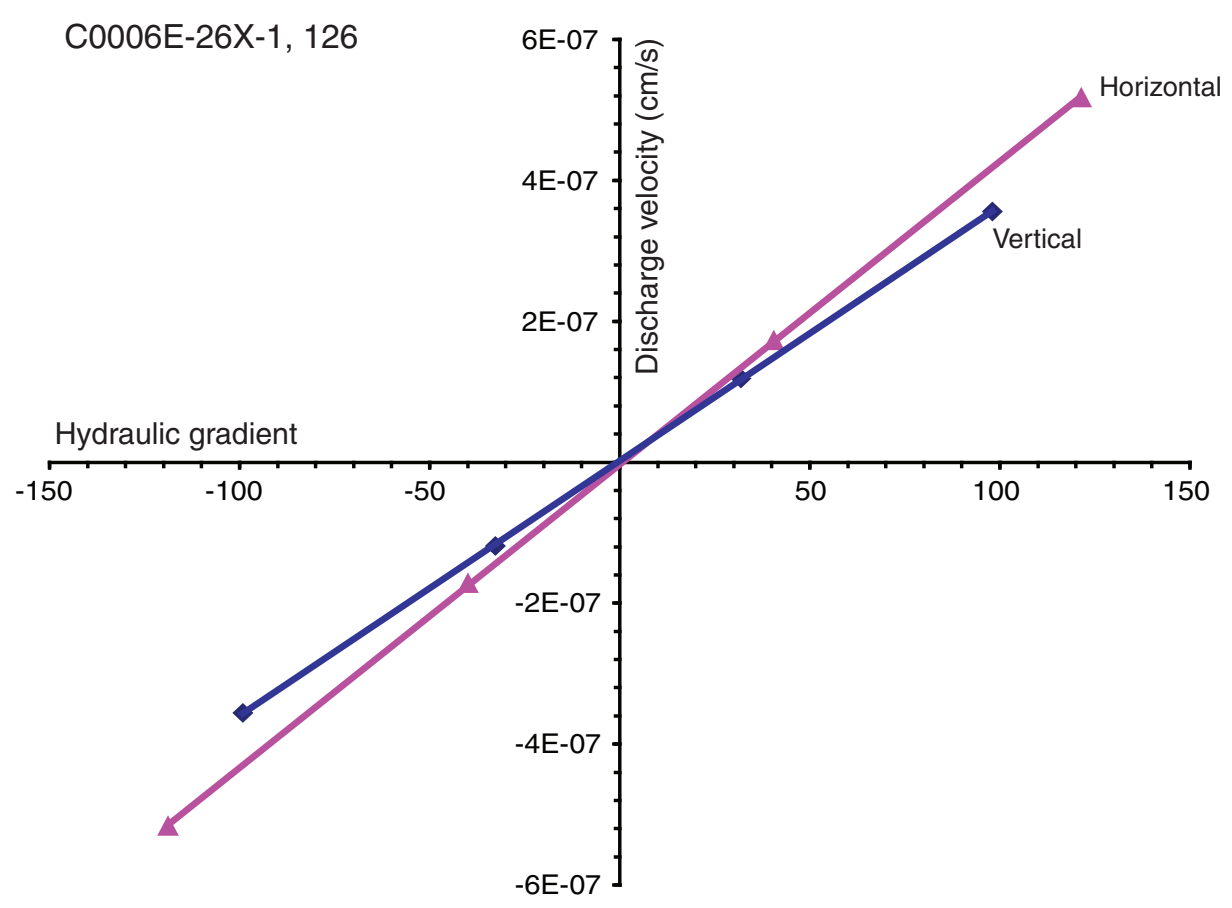


Figure AF7. Hydraulic gradient vs. discharge velocity (Sample 316-C0006E-34X-3, 95 cm).

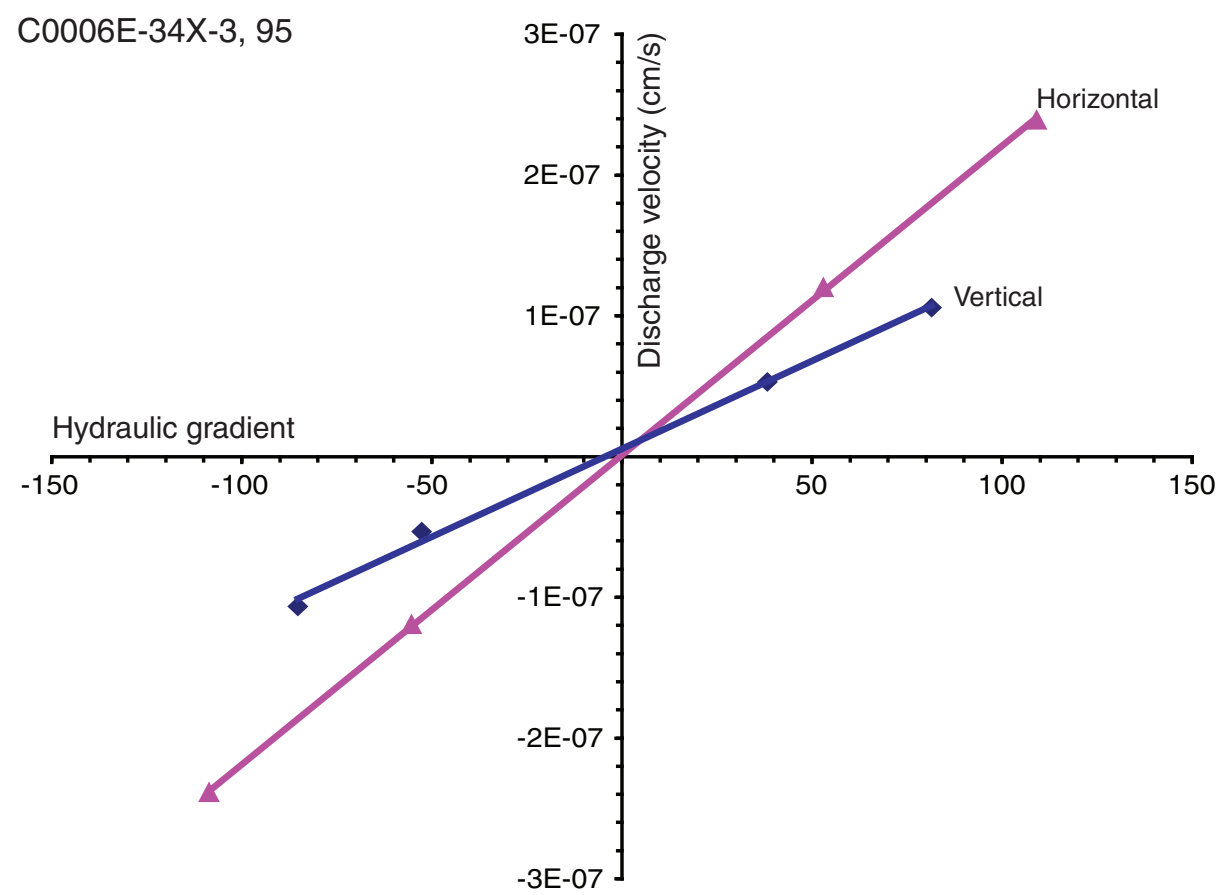


Figure AF8. Hydraulic gradient vs. discharge velocity (Sample 316-C0006E-39X-3, 48 cm).

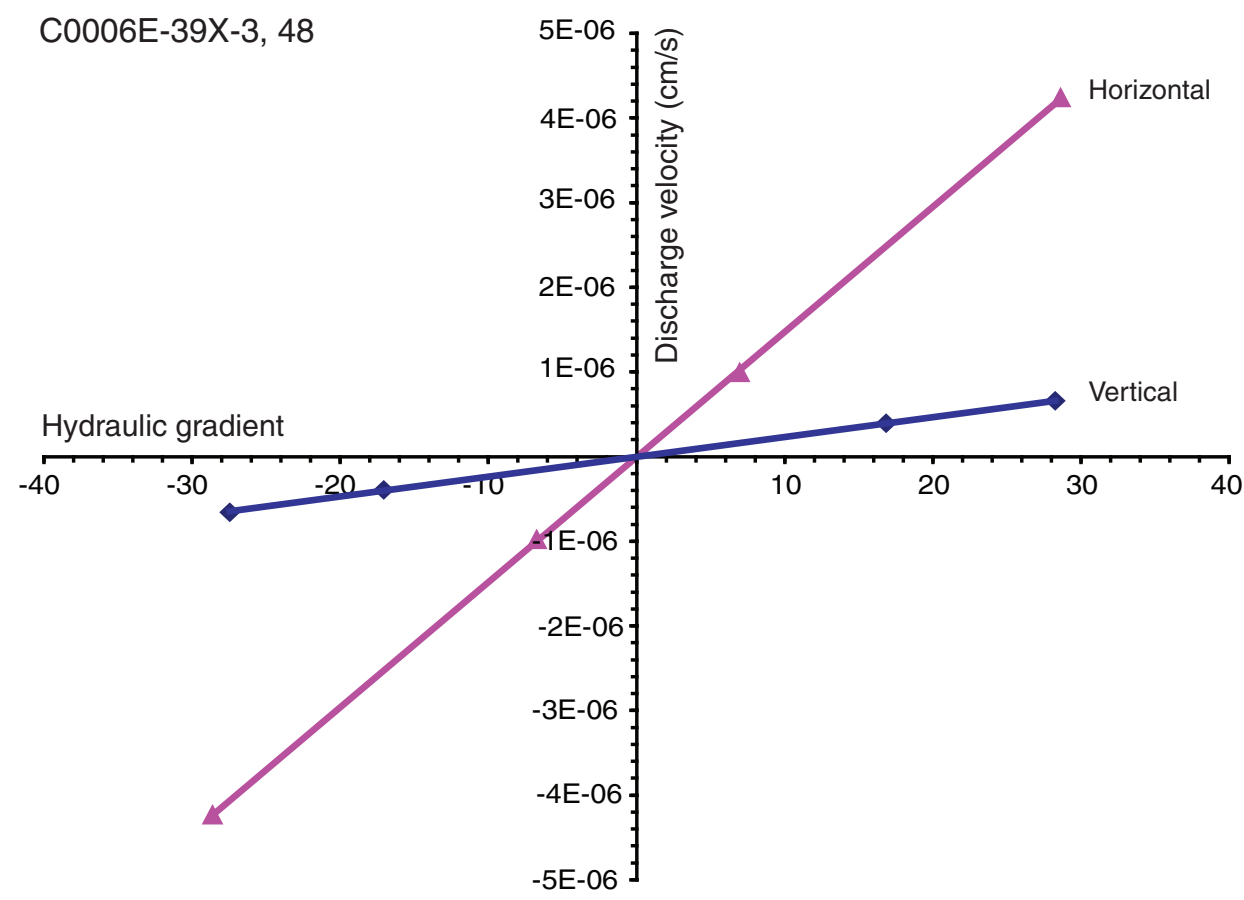


Figure AF9. Hydraulic gradient vs. discharge velocity (Sample 316-C0006F-19R- 2, 61 cm).

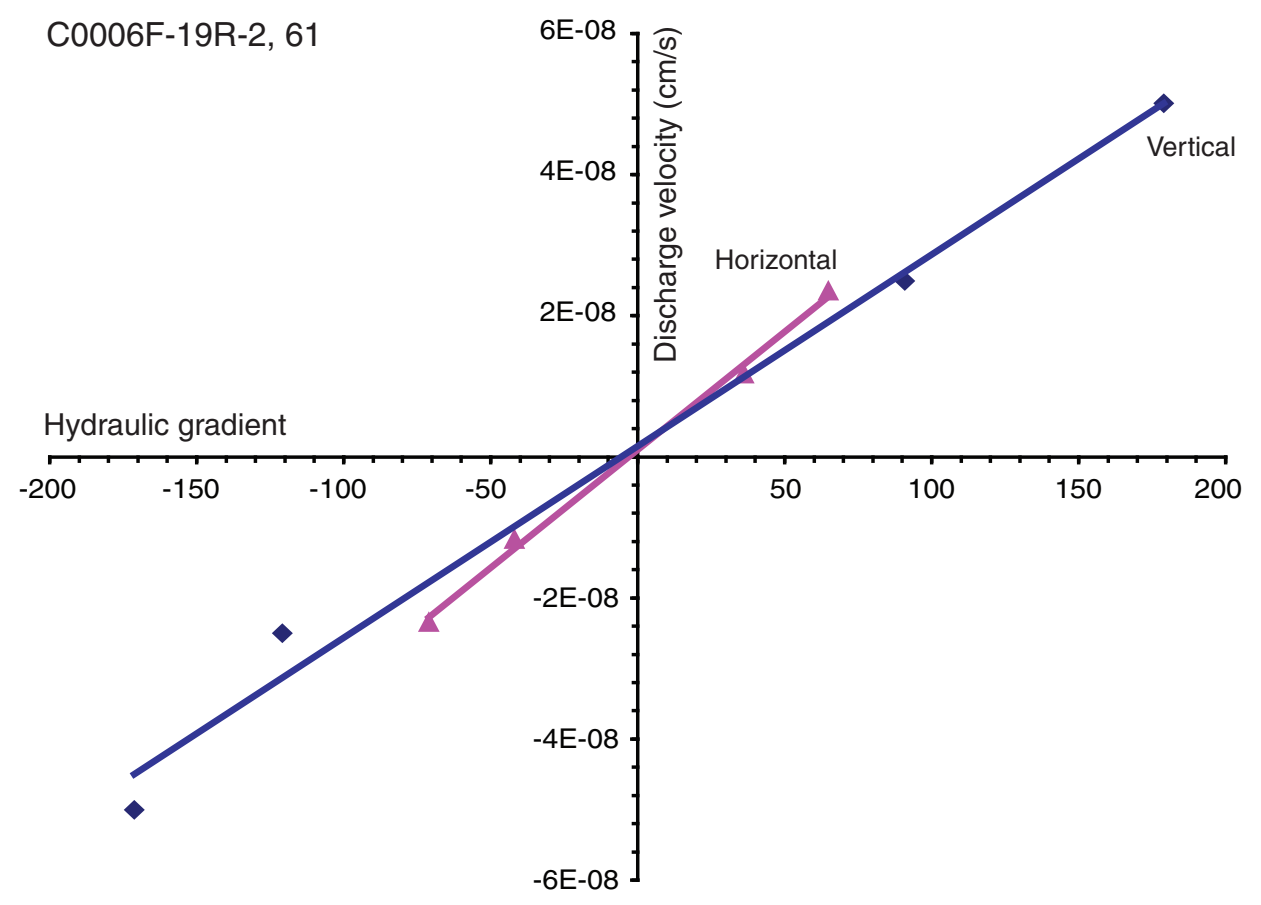


Figure AF10. Hydraulic gradient vs. discharge velocity (Sample 316-C0007D-23R-2, 97 cm).

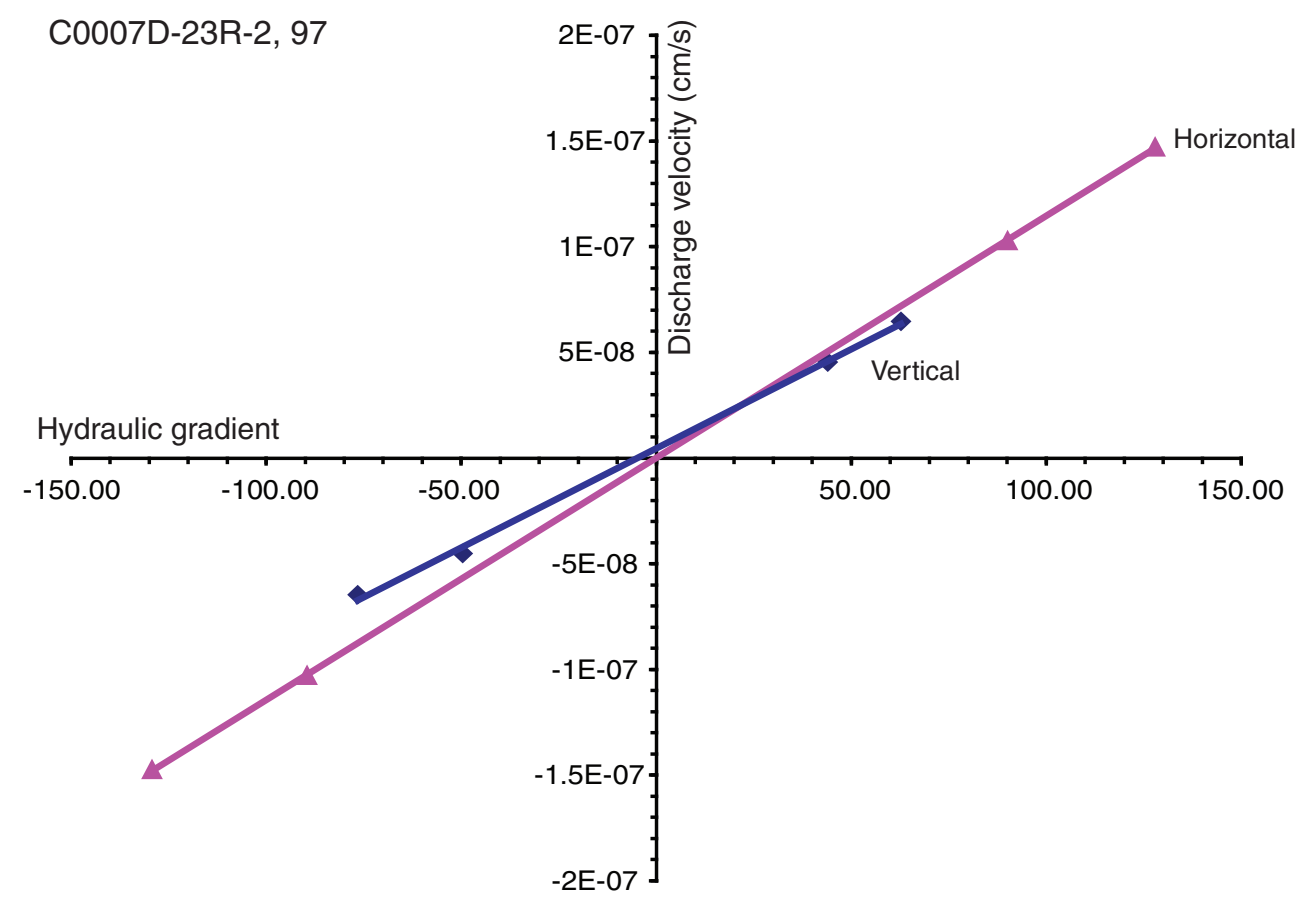


Figure AF11. Hydraulic gradient vs. discharge velocity (Sample 316-C0007D-25R-2, 66 cm).

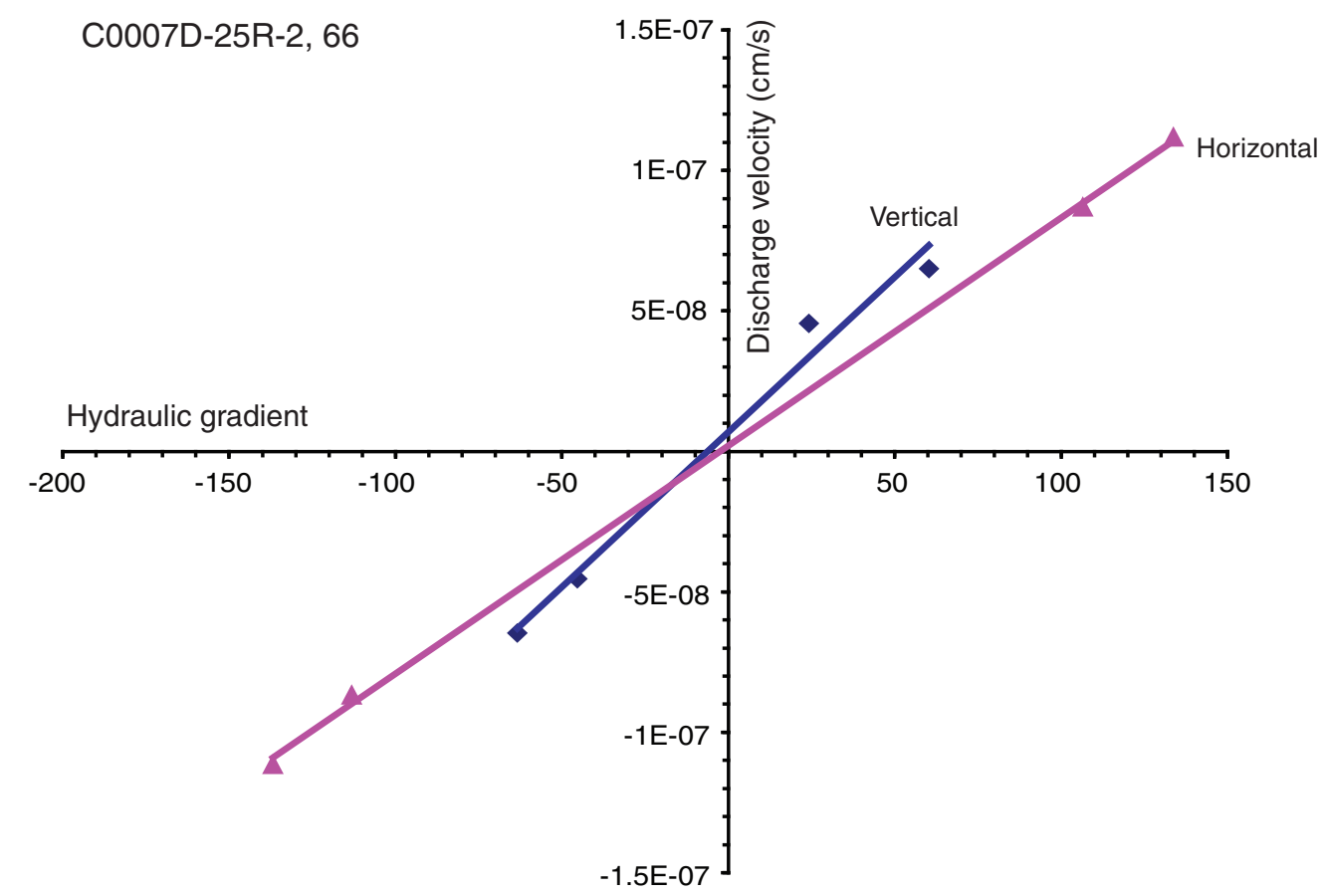

